\title{
Van Hüsrev Paşa Külliyesi Mimari Süsleme ve Onarımı
}

\section{The Architectural Decoration and Renovation of Van Hüsrev Paşa Social Complex}

\section{Sahabettin Öztürk}

Dr. Öğr. Üyesi, Van Yüzüncü Yıl Üniversitesi, Mimarlık ve Tasarım Fakültesi, Mimarlık Bölümü email: sahozturk13@gmail.com (DORCID ID: https://orcid.org/0000-0001-6979-3342

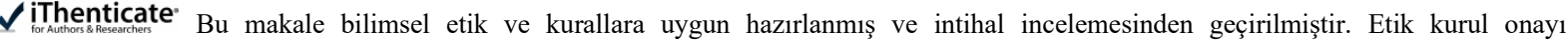
gerektirmemektedir.

\section{Atıf (APA 6)/To cite this article}

Öztürk, Ş. (2021). Van Hüsrev Paşa külliyesi mimari süsleme ve onarımı. Atatürk Üniversitesi Güzel Sanatlar Enstitüsü Dergisi, 27(46), 2343. https://doi.org/10.35247/ataunigsed.822195
\end{abstract}

Makale Gönderim Tarihi / Received: 06/11/2020

Makale Kabul Tarihi / Accepted: 16/02/2021

Makale Yayın Tarihi / Published: 29/03/2021

Research Article/Araștırma Makalesi

Öz

Eski Van Şehri'nde yer alan Hüsrev Paşa Külliyesi, Kanuni Sultan Süleyman'ın vezirlerinden Van Beylerbeyi Köse Hüsrev Mehmed Paşa tarafindan 1567-68 yıllarında inşa edilmiştir. Mimar Sinan'ın eseri olan külliye; cami, medrese, kümbet, han, çifte hamam, imaret, sıbyan mektebi, çeşme, misafirhane, firın ve dükkân bölümlerinden oluşmaktadır.

Hüsrev Paşa Külliyesi'nin merkezinde yer alan cami, medrese, imaret, kümbet ve şadırvan-avlu yapı bölümlerinde onarım çalıșmaları 2007-13 yılları arasında tamamlanmıstır. 2005-07 yılları arasında külliyeden ayrık olarak inşa edilen han ve çifte hamam kazı ve proje çalışmaları Van Valiliği tarafından tamamlanmış, ancak uygulama çalışmaları henüz yapılmamıştır.

Yapılan çalıșmanın amacı külliyede sadece cami ve kümbette yer alan süslemelerin tespitini yapmak, kalem işi, çini ve ahşap süslemenin sınıflandırmasının kendi içerisinde belirlemektir. Belirlemede her süsleme kendi onarım metoduna uygun olarak sertifikalı uzmanlar tarafından onarım aşamalarının başlangıçtan sonuna kadar tüm veriler kayıt altına almaktır.

Süslemelerin tespit ve onarım aşamalarının sonucunda elde edilen tüm görsel ve proje verilerinin kendi içerisinde, bölge ve dönem analizleri yapılmıştır. Süslemeler nitelik olarak Sanat ve Mimarlık Tarihi açısından oldukça önem arz etmektedir.

Anahtar Kelimeler: Hüsrev Paşa Külliyesi, Kalem İşi Süsleme, Çini Süsleme, Taş Süsleme, Süsleme Onarım

\section{Abstract}

Hüsrev Paşa Social Complex, located in the Old City of Van, was built between the years 1567 and 1568 by Van Governor Köse Hüsrev Mehmed Pasha, one of the viziers of Suleiman the IInd. The Social Complex which is a work of Mimar Sinan had consisted of a mosque, madrassah, cupola, inn, double hammam, almshouse, primary school, fountain, guesthouse, bakery, and store sections.

Renovation works on the mosque, madrassah, almshouse, cupola, water-tank with a fountain and yard structural sections of Hüsrev Paşa Social Complex's center were conducted and completed by Foundations Regional Directory of Bitlis between the years 2007 and 2013. Excavation works for the inn and double hammam which were built as separate sections from the social complex had been completed between the years 2005 and 2007 by Van Governorate; however, application works have not been conducted yet. The study aims to observe the decorations only on the mosque and cupola and to determine engraving, tiling, and woodworks in their classifications. During determination, all phases' data are recorded from beginning to end by certified experts for each decoration, according to their methods of renovation.
\end{abstract}

Regional and periodical analyses are done in themselves for all visual and project data which were obtained as a result of decorations' observation and renovation steps. Decorations are quite important for Arts and Architecture History.

Keywords: Hüsrev Paşa Social Complex, Decorative Painting, Tile Decorations, Engraving, Decorations' Renovation

\section{Giriş}

Hüsrev Paşa Külliyesi'nin yer aldığı Eski Van Şehri, tarihi Van Kalesi'nin güneyinde yaklaşık $365.000 \mathrm{~m}^{2}$ ' lik alan üzerine kurulmuştur (Görsel 1). Eski Van Şehri'nin doğusu, güneyi ve batısı surlarla, kuzeyi ise Van Kalesi ile çevrelenmiştir. Şehre giriş doğu, güney ve batı surlardan açılan dört ana kapı ile sağlanır (Öztürk, 2004, s. 5254; Tarhan, 1985, s. 297-355).

\section{Görsel 1}

Van Kalesi ve Eski Van Şehir Güneydoğu Genel Görünüşü

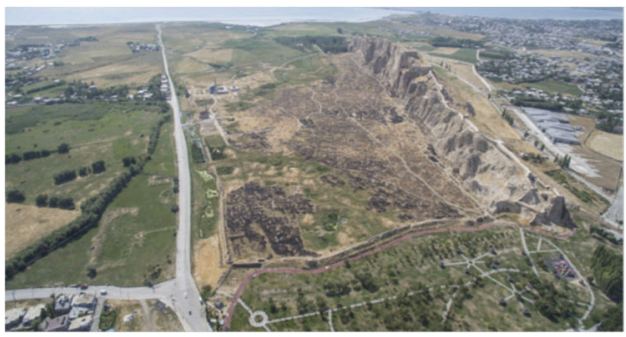

(VANTAM, t.y.). 
Şehirdeki Müslümanlar ile Ermeniler yan yana, iyi komşuluk ilişkisi içinde yüz yıllarca birlikte kardeşçe yaşamışlardır. 1915-18 Rus-Ermeni işgali sırasında şehirdeki tüm mimari yapılar yakılıp yıkılarak yok edilmiştir. Bu tarihten 2010 yılına kadar doğanın ve diğer her türlü olumsuz koşulların etkisi altında yıkılan mimari yapılardan biri de Hüsrev Paşa Külliyesi’dir.

Eski Van Şehri’nin Orta Mahallesi’nde yer alan Hüsrev Paşa Külliyesi, cami, şadırvan, medrese, imaret, sibyan okulu, hazire, çeşme, kümbet, han ve çifte hamam yapı bölümlerinden oluşmaktadır (Öztürk, 1996, s. 14-19). Han ve Çifte Hamam külliye yapı topluğundan ayrı olarak şehrin doğusunda inşa edilmiştir. Hüsrev Paşa Külliyesi, Vakıflar Genel Müdürlüğü Bitlis Vakıflar Bölge Müdürlüğü tarafından farklı tarihlerde dört kez onarılmıştır. Külliyede son olarak esaslı onarım çalışmaları ise 2007-13 yılları arasında tamamlanmıştır.

Günümüzde onarılan külliye bölümlerinden cami, şadırvan, avlu, medrese, imaret ve kümbet aktif olarak dini, sosyal ve kültürel amaçlı faaliyetlerde kullanılmaktadır (Görsel 2). Hüsrev Paşa Külliyesi, Kanuni Sultan Süleyman'ın vezirlerinden Van Beylerbeyi Hüsrev Paşa tarafından, H.975-M.1567-68 tarihinde inşa edilmiş olup Sanat Tarihi ve Mimarlık Tarihi içerisinde önemli bir yeri vardır (Ağaoğlu, 2007, s. 328-330; Öztürk, 2019, s. 452-469; Sönmez, 1988, s. 84).

\section{Görsel 2}

Hüsrev Paşa Külliyesi Güneybatı Genel Görünüşü

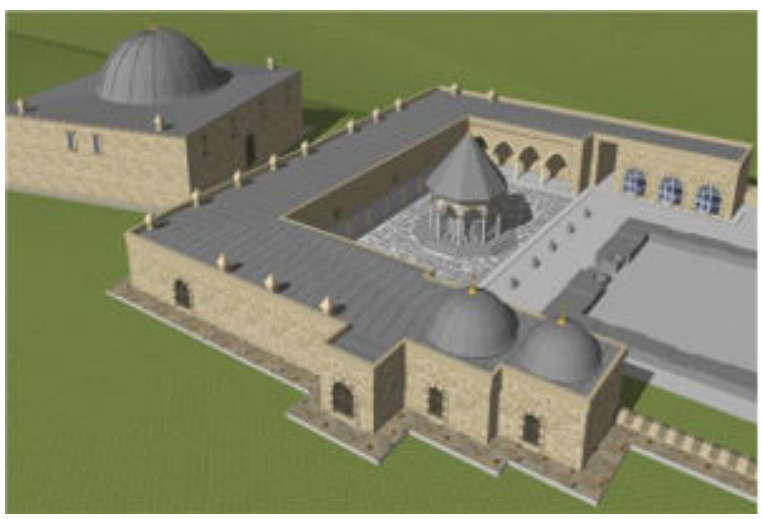

(Öztürk, t.y.).

Cami, ilgili kurul tarafından 08.06.1979 tarih ve A-1673 sayılı karar ile anıt yapı olarak tescil edilmiştir. Caminin giriş kapısı üzerinde Celi Sülüs harflerle yazılmış iki beyitlik tarih kitabesi yer almaktadır. Farsça yazılı kitabede Beylerbeyi Hüsrev Paşa ve hattat Yusuf'un adları okunmaktadır. Kaynaklarda yapının mimarı olarak Van Eyaleti Hassa mimarı olan mimar Selman'ın görevlendirildiği ve cami planının başkent İstanbul'dan gönderildiği belirtilmiştir (Kılıç, 1997, s. 27; Uluçam, 2000, s. 5). Hüsrev Paşa Külliyesi, Tuhfet ül-Mi'marin'de Mimar Sinan eserleri arasında 72. sırada geçmekte ve külliyenin cami, medrese, türbe, imaret, sıbyan mektebi, daru'l-kurra, mualim ve misafirhaneden oluştuğu belirtilmektedir (Sönmez, 1988, s. 84; Meriç, 1965, s. 27; Kuran, 1986, s. 257). Hüsrev Paşa Külliyesi her ne kadar Mimar Sinan'1n eseri olarak belirtilse de, Mimar Sinan'a atfedilen diğer birçok yapı gibi, de Sinan'ın onayladığı bir başka eyalet mimarı tarafından inşa edildiği düşünülmektedir (Eyice, 1999, s. 50).

\section{Yöntem}

Araştırma betimsel ve uygulama modeline dayalı olarak yapılmıştır. Betimsel ve uygulama araştırma modelleri araştırma ve uygulama yöntemiyle yürütülmüş̧ür. Araştırmada Van merkez İpekyolu İlçesi’ndeki Eski Van Şehri'nde yer alan Hüsrev Paşa Külliyesi'nde yapılan süsleme onarım çalışmaları gözlem, araştırma ve uygulama teknikleri kullanılarak süsleme özellikleri çeşitli gruplara ayrılarak detaylıca incelenmiş ve uygulaması yapılmıştır.

\section{Hüsrev Paşa Külliyesi'nde Süsleme}

Külliyeyi oluşturan yapılarda kullanılan süslemeler ağırlıklı olarak cami ve kümbette yer alır. Külliyenin tamamlayıcı yapılarından olan sıbyan okulu ve çeşmenin mimari yapısı günümüzde mevcut olmadığı için, süslemesi hakkında yeterince bilgiye sahip değiliz. Diğer yapılarda süsleme unsuruna rastlanmamıştır. Külliyede son olarak 2007-13 yılları arasında Bitlis Vakıflar Bölge Müdürlüğü tarafından esaslı onarım çalışmalarına paralel olarak süsleme onarımı da yapılmıştır. Hüsrev Paşa Külliyesi’nde kullanılan süslemeleri dört ana başlık altında toplayıp ayrı ayrı değerlendirmek mümkündür (Öztürk, 2020a, s. 1237-1268). 


\subsection{Kalem İşi Süsleme}

Hüsrev Paşa Külliyesi, cami giriş kapısı üzerindeki kemer alınlığında, tromplarda, mihrapta, iç duvar satıhlarında ve kemerlerde geç dönemde alçı sıva üzerinde Barok motifli kalem işi süslemeler yapılmıştır. Yapılan bu kalem işi süslemelerin kesin tarihi ve kim tarafından yapıldı̆̆ına dair herhangi bir bilgiye sahip değiliz.

\section{Görsel 3}

Hüsrev Paşa Camii Giriş Kapısı Kalem İşi Süsleme Temizlik Görünüşüleri

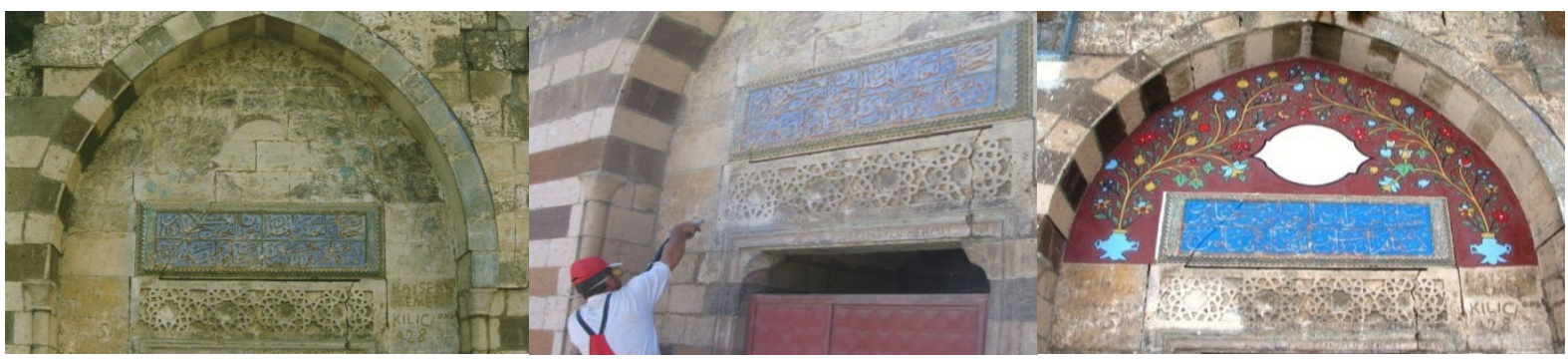

(Öztürk, t.y.).

Külliyede cami dışında diğer tamamlayıcı yapılarında kalem işi süslemeye rastlanmamıştır. Yapıda kullanılan kalem işi süsleme motifleri Osmanlı klasik süsleme özelliğindedir. Cami giriș kapısının üzerindeki kemer alınlığında yer alan süslemenin ortasındaki madalyon formundaki şemse motifinin içi boştur. Şemse motifinin iki yanında simetrik vazolarda çıkan çiçek ve stilize edilmiş ağaç dalları yer alır. Süsleme; nar çiçeği, gül ve gül goncası, hurma, üzüm salkımı, yıldız çiçeği ve küçük kır çiçekleri ile farklı ebatlardaki yapraklardan oluşmaktadır. Nar, hurma ve üzüm meyvelerinin üçünün bir arada kullanılması cenneti simgeleyen meyveler tasvir edilmektedir. Panodaki gonca gül penc ve hatailerin açılmamış olarak stilize edilmiştir (Belli, 2009, s. 6379), (Görsel 3-4).

\section{Görsel 4}

Hüsrev Paşa Camii Giriş Kapısı Kalem İşi Süsleme Onarım Görünüşleri
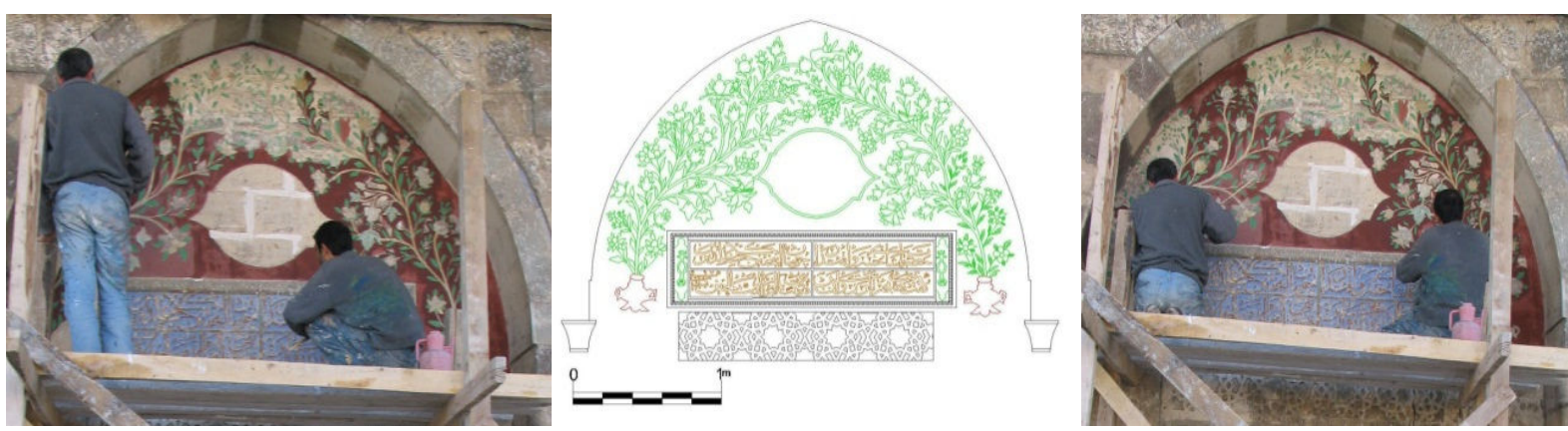

(Öztürk, t.y.).

Caminin iç mekân kubbeye geçiş sağlayan kirpi saçağın hemen altında yer alan kandil motiflerinden oluşan süsleme ile çevrelenmiştir. Beyaz zemin üzerinde mavi içbükey askının her iki yanında yer alan armudi gövdeli kırmızı renkli siyah kontörlü kandiller düzenli bir şekilde sıralanmıştır. Kandil motifi Osmanlı kalem işi sanatında çokça kullanılan bir motif türüdür (Görsel 5-6).

\section{Görsel 5}

Hüsrev Paşa Camii Kandil Süsleme Onarım Öncesi Görünüşü

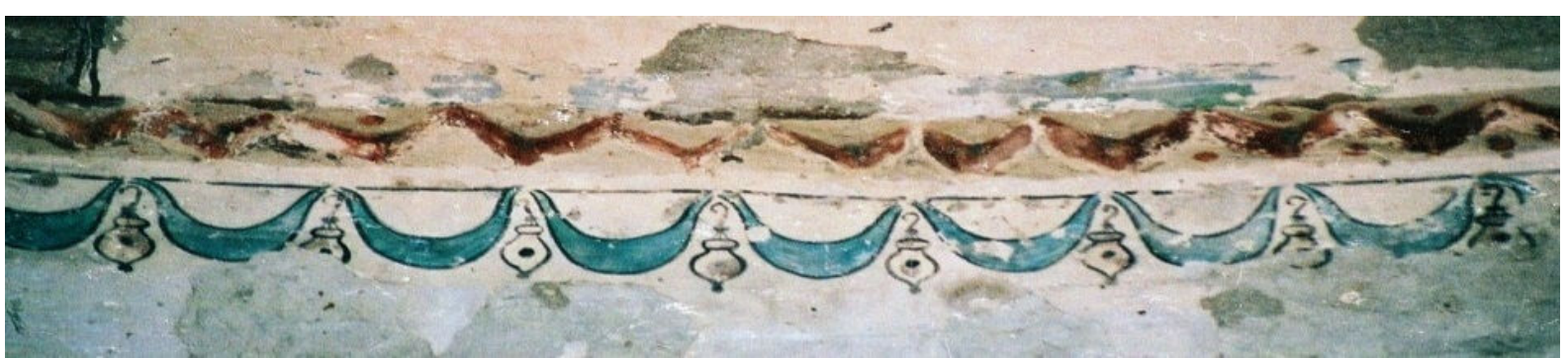

(Öztürk, t.y.). 
Kandil motifinin üstünde kırmızı zikzak motifinin alt ve üst zikzak bölümlerine alt ve üstlerine küçük birer daire yerleştirilmiştir. Kirpi saçağının üst kısmı ise yeşil renkli bir bant ile çevrelenmiştir.

\section{Görsel 6}

Hüsrev Paşa Camii Kandil Süsleme Çizimi ve Onarım Sonrası Görünüşü

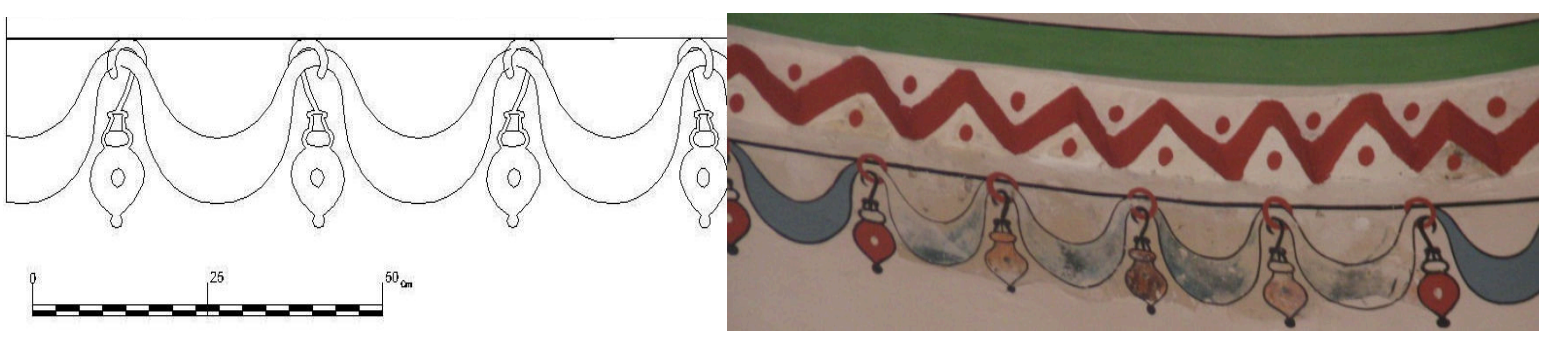

(Öztürk, t.y.).

Caminin iç mekan köşelerinde yer alan dört adet tromp geçişlerinin üst bölümünün her iki yanında toplam sekiz adet simetrik olarak tasarlanmış madolyan süsleme yer alır. Barok kıvrımlarının meydana getirdiği çember formundaki koyu kırmızı madalyonların etrafındaki natüralist bitkisel motifli süslemeler simetrik olarak düzenlenmiştir.

\section{Görsel 7}

Hüsrev Paşa Camii Kemer ve Saçak Süsleme Onarım Oncesi Genel Görünüşü

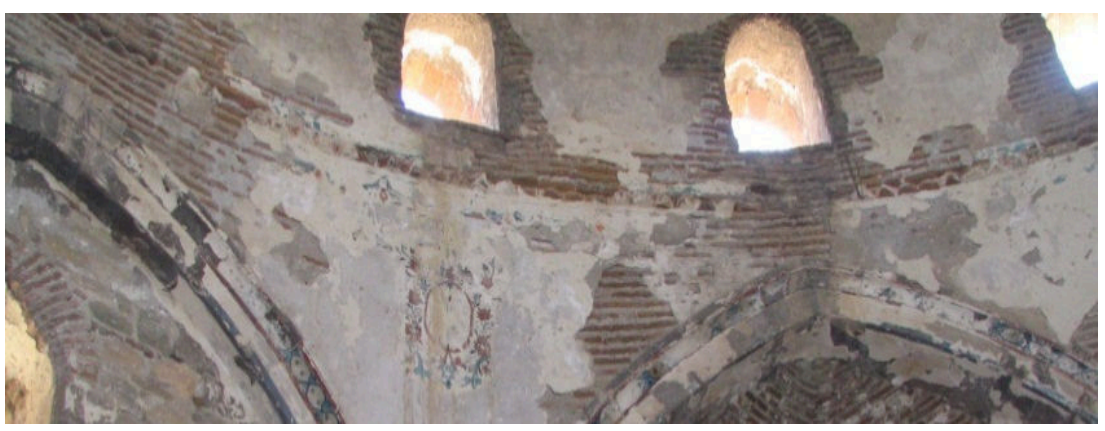

(Öztürk, t.y.).

Madalyonun içinden çıkan simetrik iki dalın uçları ve uçlarındaki motiflerle bezelidir. Madalyonun çevresindeki gül, gül goncası hatai çiçeği çeşitli büyüklükte hançer yaprakları ve barok kıvrımları ile donatılıdır. Madalyonun üst kısmında hatai çiçekleriyle birlikte iki hançer yaprağı görülmektedir. Alt kısımda ise tek başına diğerlerinden biraz daha büyük hatai çiçeği yer almaktadır.

\section{Görsel 8}

Hüsrev Paşa Camii Madolyon Süsleme Onarım Oncesi Görünüşleri

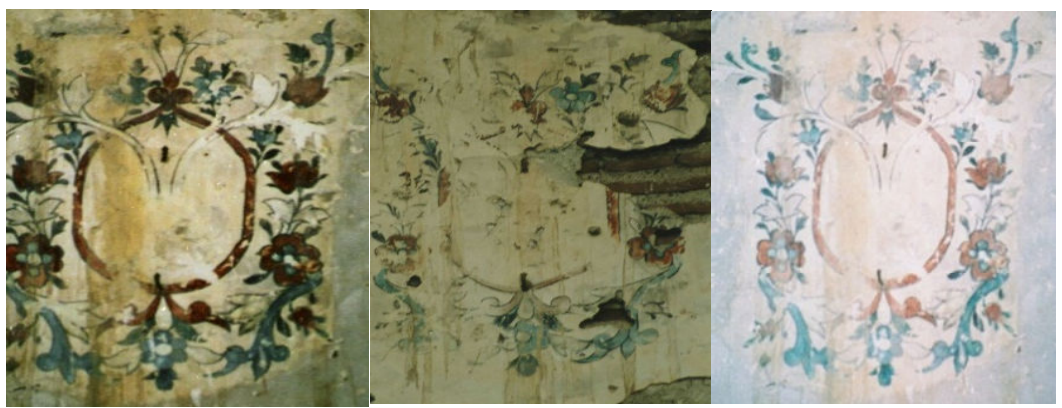

(Öztürk, t.y.).

Açılmış gül ve gül goncasının üzerinde dilimli yaprak ve hançer yaprakları ile donatılıdır. Madalyodaki yaprak ve dallarının bazıları nefli beyazla yapılmıştır. Madalyoda kırmızı ve mavi renkler hakim olmakla birlikte yeşil renkte kullanılmıştır (Görsel 7-9). 


\section{Görsel 9}

Hüsrev Paşa Camii Madolyon Motifi Süsleme Onarım Sonrası Görünüşleri ve Çizimi
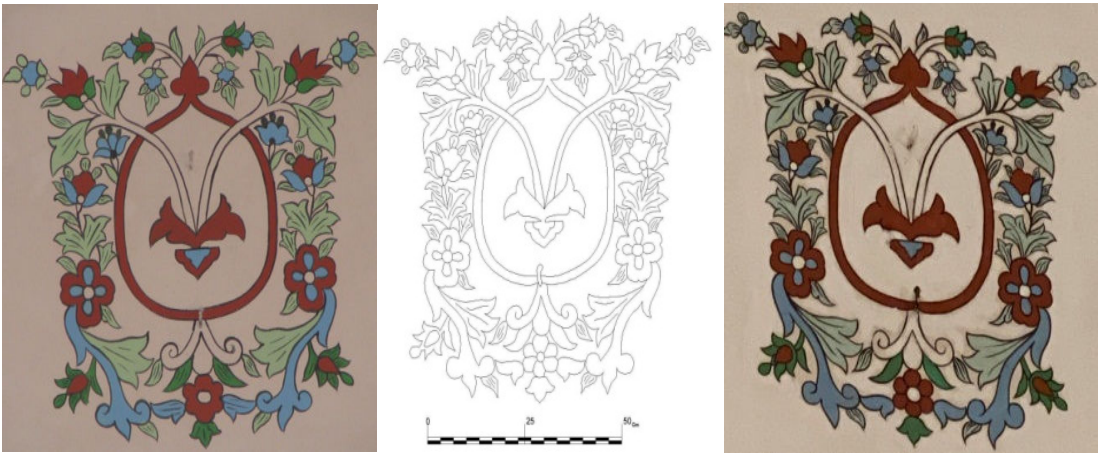

(Öztürk, t.y.).

Trompların iç kısmının her iki yanında, doğu ve batı duvarlarında yer alan yuvarlak kemerli panolar simetrik olarak yerleştirilmiş, zengin bitkisel süsleme ile donatılıdır. On adet olan bu panoların iç bölümü bitkisel motiflerde yaprak, gül ve gül goncası ile bezelidir (Görsel 10-11).

\section{Görsel 10}

Hüsrev Paşa Camii Pano Süsleme Onarım Öncesi Genel Görünüşü

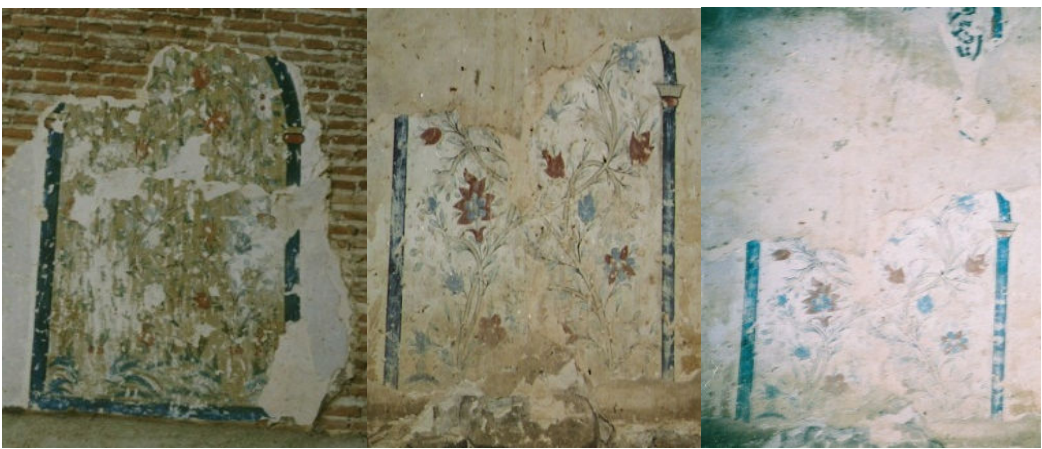

(Öztürk, t.y.).

Panonun alt kısmındaki simetrik iki vazodan çıkan kalın bir dal, yukarı doğru simetrik kıvrımlar yaparak hançer yaprağı, gül ve gül goncası ile donatılmıştır. Dalları birbirine dolanarak ilerlenmesi sarmaşık çiçeğini anımsatmaktadır.

\section{Görsel 11}

Hüsrev Paşa Camii Pano Süsleme Onarım Sonrası Çizim ve Görünüşleri
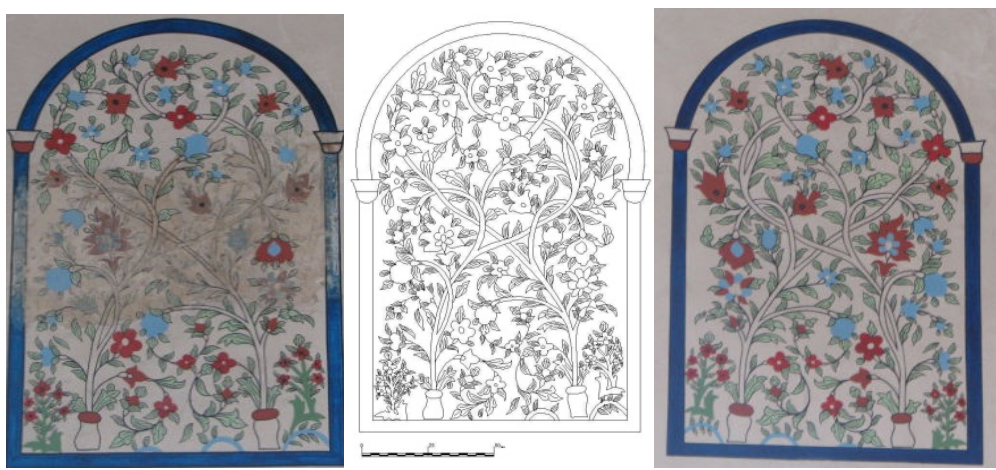

(Öztürk, t.y.).

Mihrabın üstünde yer alan kalem işi süsleme motifinin ortasındaki vazodan çıkan kalın dal içe ve dışa doğru kıvrılarak simetrik olarak düzenlenmiştir. Motifte ağırlıklı olarak kırmızı, mavi ve yeşil renkler kullanılmıştır. Madalyonda gül, gül goncası hatai çiçeği çeşitli büyüklükte hançer yaprakları ve barok kıvrımları ile donatılıdır (Görsel 12). 


\section{Görsel 12}

Hüsrev Paşa Camii Mihrap Üstü Süsleme Motifi Onarım Sonrass Görünüşü ve Çizimi
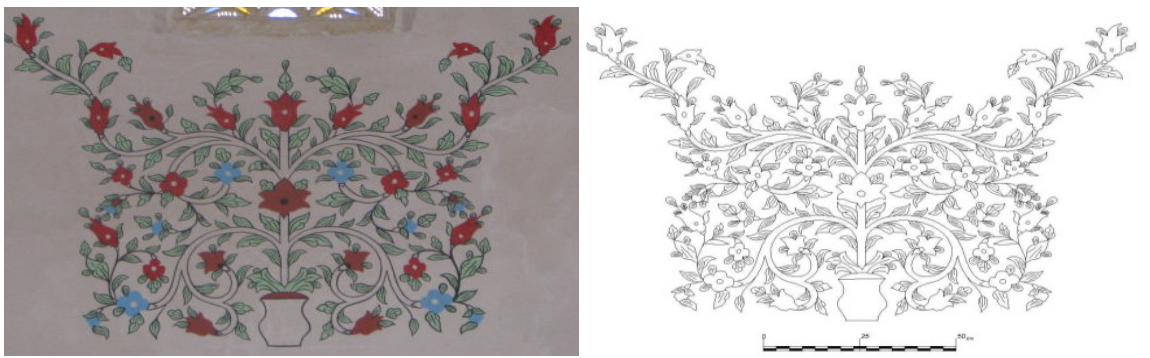

(Öztürk, t.y.).

Cami iç mekanında kemerlerin yüzeylerinde kırmızı renkli şerid içerisinde mavi zemin üzerinde şems motifi için beş yapraklı hatai çiçeği yanında hançer yaprakları ile donatılmıştır (Görsel 13-14). Kemerlerin başlangıç bölümü üç dilimli mukarnas süsleme ile donatılmş, içerisi kırmızı çevresi ise mavi kontur ile tüm kemer boyunca çevrelenmiştir.

\section{Görsel 13}

Hüsrev Paşa Camii Kemer Kalem İşi Süsleme Çizimleri

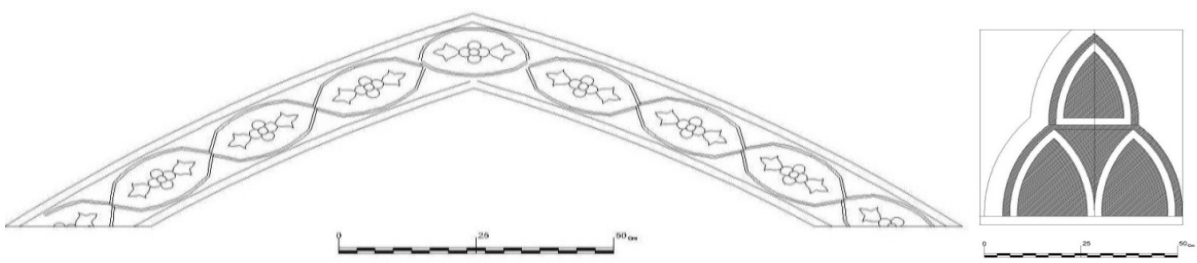

(Öztürk, t.y.).

\section{Görsel 14}

Hüsrev Paşa Camii Kemer Kalem İşi Süsleme Öncesi Görünüşleri
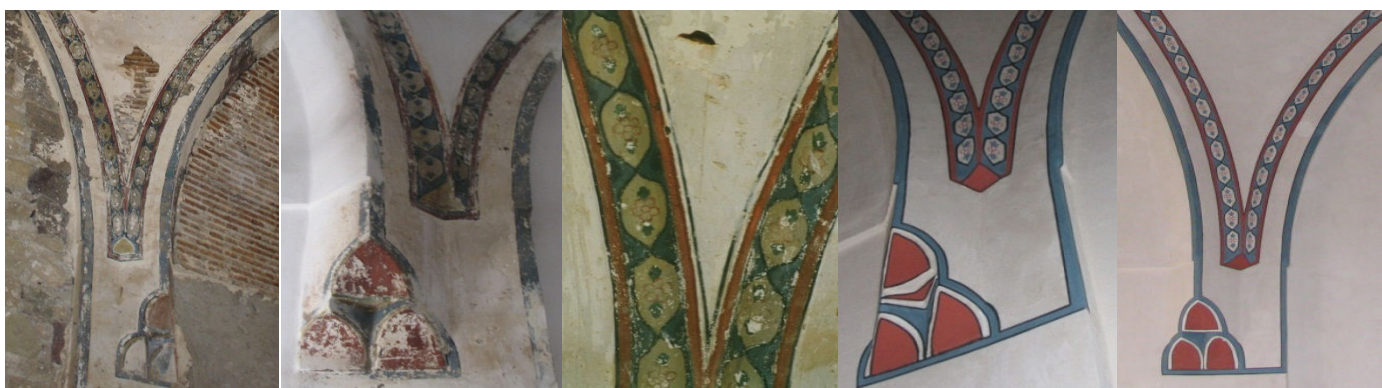

(Öztürk, t.y.).

Cami iç mekanının doğu ve batı beden duvarlarında yer alan kalem işi yuvarlak kemerli panoların üzerine karş1lıklı olarak yerleştirilen madalyon süslemeli motifler yerleştirilmiştir. Beyaz bir zemin üzerine siyah renkle bezeli sekiz kollu yıldızın çevresi hat sanatı ile donatılıdır. Yıldız kolları Ya Burhan, Ya Deyyan, Esma-i Hüsna dan ikisi olan Celi Sülüs yazı tarzında yazılmış, dairesel motifin çevresi kırmızı ve mavi renkler ile çevrelenmiştir (Görsel 15).

\section{Görsel 15}

Hüsrev Paşa Camii Madalyon Çizim ve Onarım Sonrası Görünüşleri

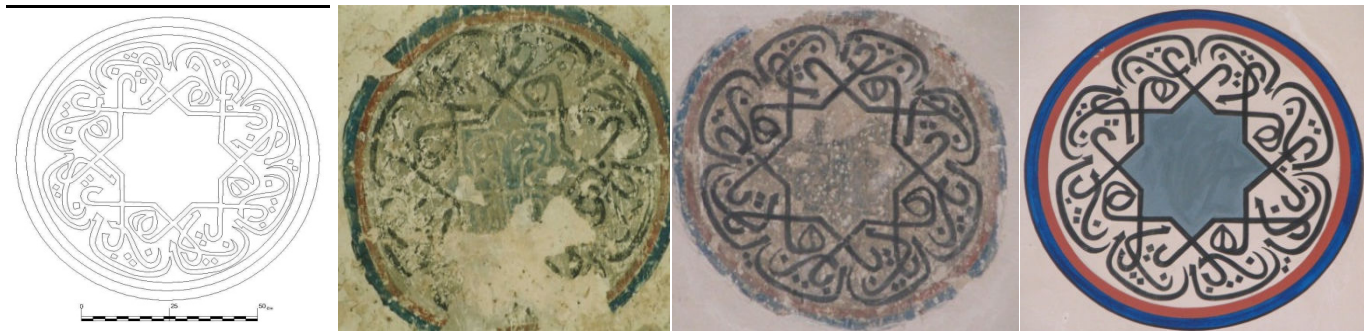

(Öztürk, t.y.). 
Geç dönem camideki yapılan alçı üzeri kalem işi süslemelerin yer aldığı yerlerden biride mihraptır. Taş süslemeli altın varak ile donatılı mihrabın tüm yüzeyi geç dönemde alçı üzeri kalem işi renkli motifler ile süslenmiştir. Ancak kalem işi motifler son dönemde defineciler tarafindan çokça tahrip edildiğinden süslemelerin bütünlüğü net olarak bilinmemektedir. Sadece mihrabın üst kısımlarındaki süslemelerin bir bölümü mevcuttur.

\section{Görsel 16}

Hüsrev Paşa Camii Mihrap Onarım Öncesi Kalem Işsi Süsleme Görünüşleri

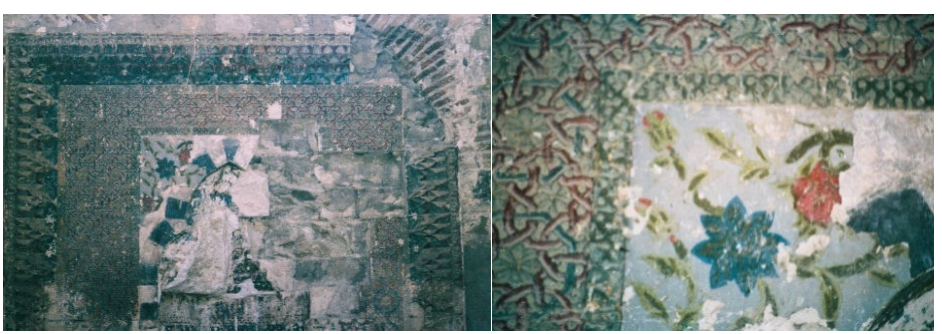

(Öztürk, t.y.).

Mihrabın alçı sıva ile sıvanmış gül, gül goncası, katmerli gül motifi çeşitli kıvrımlardan oluşmaktadır. Katmerli gül kırmızı renkte yeşil kontür ile sınırları belirlenmiştir. Gül goncası ise açık ve koyu yeşil renk ile boyalıdır. Mihrabın çevresinde yer alan tüm geometrik ve mukarnas süslemelerde ise ağırlıklı olarak yeşil ve mavi kök boyalar kullanılmıştır.

Mihrap onarımı ve temizlik çalışmalarında temizlenen mihrap sathı üzerine kapatılan özgün geometrik süslemeler ile iki dilimi mihrap kemerli renkli taşlar ortaya çıkarılmıştır (Görsel 16). Süsleme onarımı, konusunda uzman kalem işi sertifikalı ustalar tarafindan yapıldı (Belli, 2009, s. 63-79). Alçı üzerine kalem işi süslemesinin yapıldığı caminin değişik yerlerindeki tüm motiflerin onarımı yapılmadan önce, parşömen kâğıdı kullanılarak motiflerin stampajları çıkartıldı. Hazırlanan süsleme motif stampajları uzman teknik elemanlar yardımıyla örnek motif kalıpları çıkartıldı. Tüm süsleme motiflerinin yüzey temizliği herhangi bir kimyasal madde kullanmadan itina ile yapıldı.

\section{Görsel 17}

Hüsrev Paşa Camii Iç Mekan Süsleme Genel Görünüşü

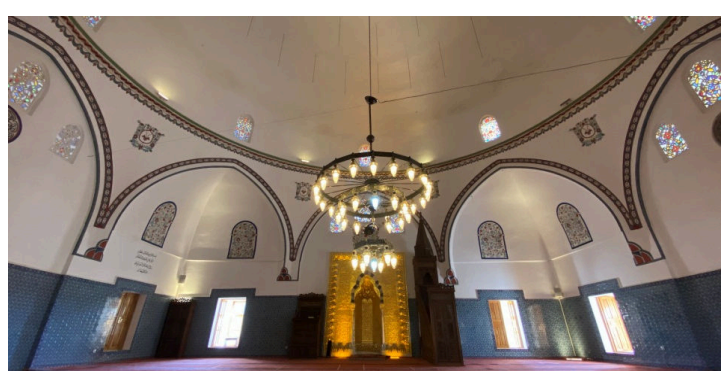

(Öztürk, t.y.).

Kalem işi onarımlarda kullanılan boyaların örnek numuneleri kimya laboratuvarlarında yapılan analizlerin sonucunda hazırlanan kök boyalar yapıldı. Onarımları yapılan süsleme motiflerinin bir kısmının özgün hali olduğu gibi bırakılarak onarımı yapıldı (Görsel 17-20).

\section{2. Çini Süsleme}

\section{Görsel 18}

Hüsrev Paşa Camii Özgün Çini Görünüşüleri
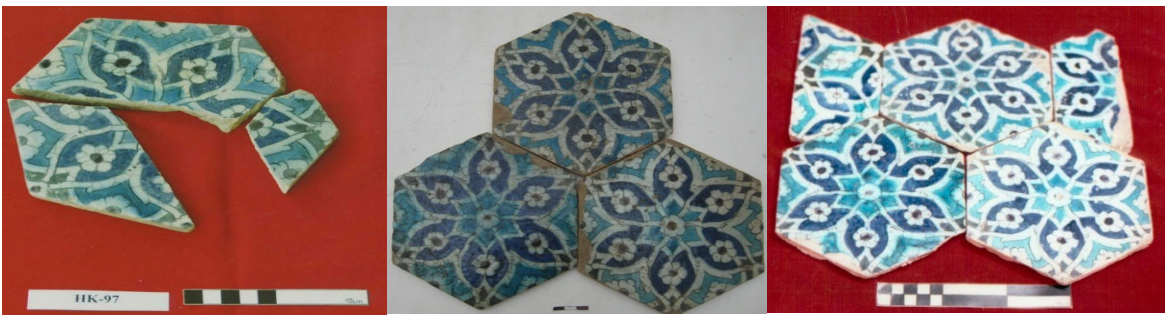

(Van Müzesi, t.y.). 


\section{Görsel 19}

Hüsrev Paşa Camii Çini Çizim Detaylarl ve Görünüşleri
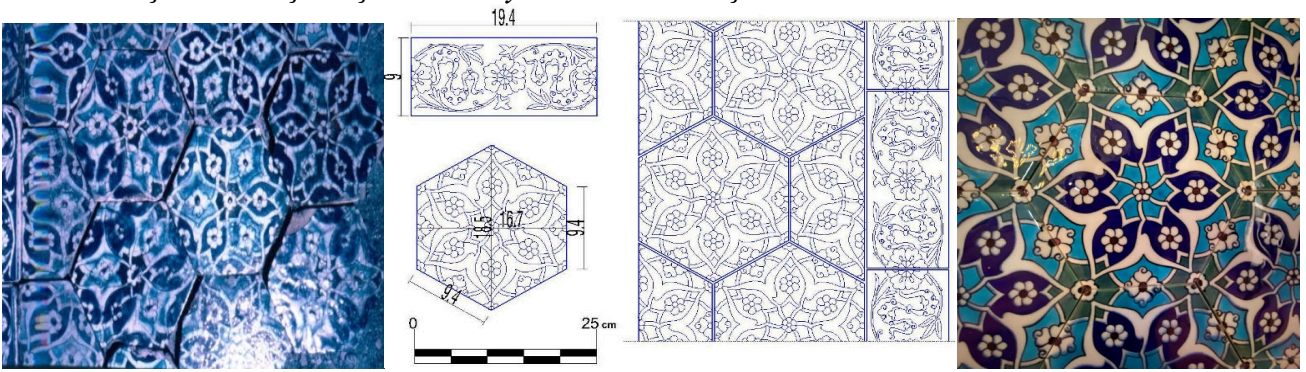

(Van Müzesi, t.y.).

Osmanlı çini sanatında XVI. yüzyıl ortasından başlanarak renkli sır tekniği terkedilmiş ve Hüsrev Paşa Camii çinilerinde de karşılaştığımız sır altı tekniği kullanılmaya başlanmıştır. Sır altı tekniği XVI. yüzyıl çini sanatında görülen ikinci ve en büyük üslup olarak kabul edilmektedir (Aslanapa, 1999, s. 323; Öney 1976, s. 86-87).

\section{Görsel 20}

Hüsrev Paşa Camii Onarım Sonrası Çini Görünüşü

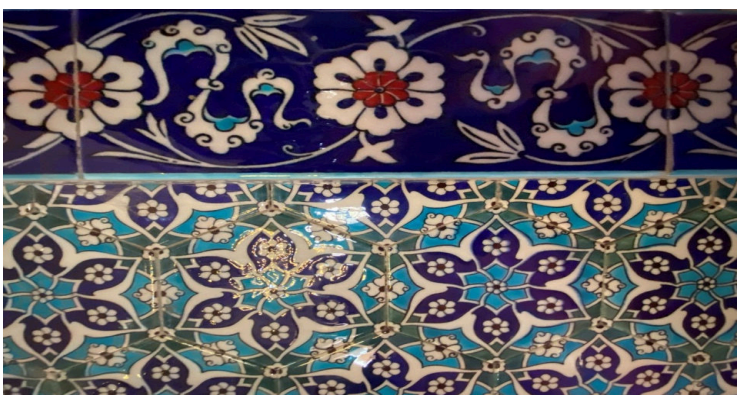

(Van Müzesi, t.y.).

XVI. yüzyılda Mimar Sinan'ın inşa ettiği yapılarda çini bezemeler mihraplarda, mihrap duvarlarında, pencere ve kemer köşeleri ve çevresinde, pandantiflerde, ayaklarda ve minber külahlarında kullanıldığı görülmektedir (Dönmez, 2001, s. 58). Mimar Sinan dönemi çinicilik, renkli sır ve sır altına boyama tekniği olarak iki grupta incelenebilir.

\section{Görsel 21}

Hüsrev Paşa Camii Özgün Çini Örnekleri Van Müze Depo Görünüşü

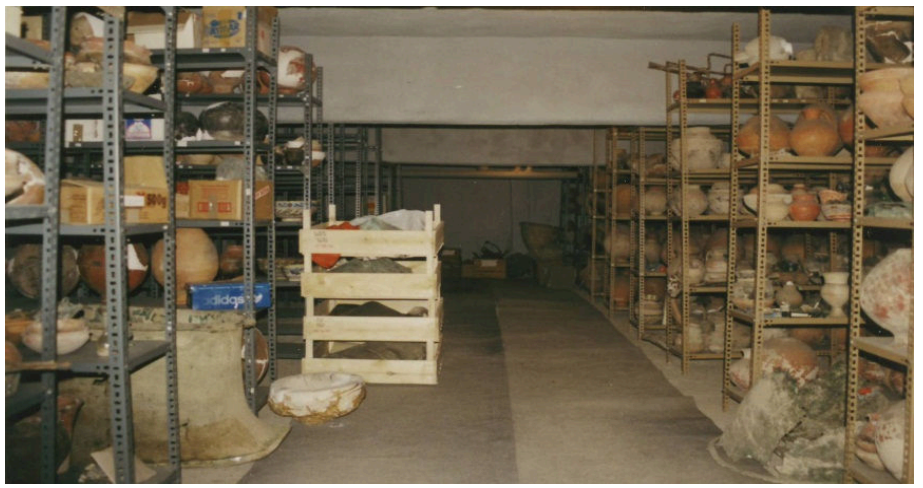

(Belli, 2009).

XVI. yüzyılda, kullanımı moda haline gelen sır altı boyama tekniği, XVIII. yüzyıla kadar kullanılmıştır. Kanuni Sultan Süleyman dönemi çiniciliğinde 1550'lerden önce soyut ve yüzeyi diklemesine dolduran çiniler, 1550’lerden sonra belirli bir yöne bağlı kalmayıp dağılmış ve natüralist öğeler kullanılmıştır. Hüsrev Paşa Camii içerisinde arkeolojik kazı ve temizlik çalışmaları sırasında, ortaya çıkan çini parçaları yapının diğer bezemesi olan kalem işleriyle yaklaşık olarak aynı döneme tarihlendirilmektedir. Sır atlı tekniği ile yapılan çinilerin İznik’ten getirildiği kaynaklarda belirtilmiştir. Ortaya çıkan çinilerde genel renk olarak yeşil, lacivert, mavi ve siyah konturlar kullanılmıştır. Farklı olarak dikdörtgen panoda kullanılan renklerde mercan kırmızısı hakimdir (Belli, 2009, 34-62; Mercan, 2001, s. 67). 


\section{Görsel 22}

Hüsrev Paşa Camii Özgün Çini Örnekleri Van Müze Depo Görünüşü

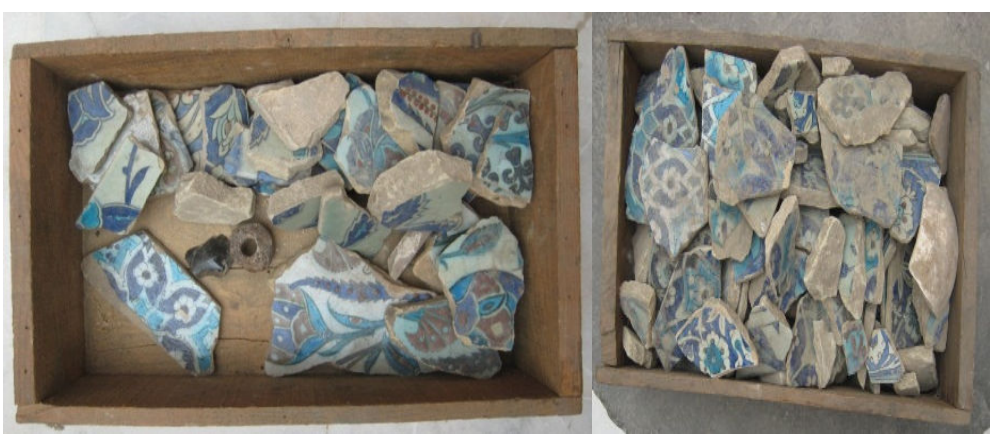

(Belli, 2009).

Eski Van Şehri'nde 1915'te yaşanan savaşta, caminin iç duvarlardaki çinilerle kaplı olan levhalarının sökülerek, Leningrad St. Petersburg Müzesi'ne götürüldügü belirtilmektedir (Boran, 1994, s. 28; Aytekin, 1995, s. 204-205; Mercan, 2001, s. 67). Günümüze kadar ulaşan az sayıda özgün çini parçaları, Van Müzesi’nin deposunda bulunmaktadır.

\section{Görsel 23}

Hüsrev Paşa Camii Çini Bordür Görünüşleri

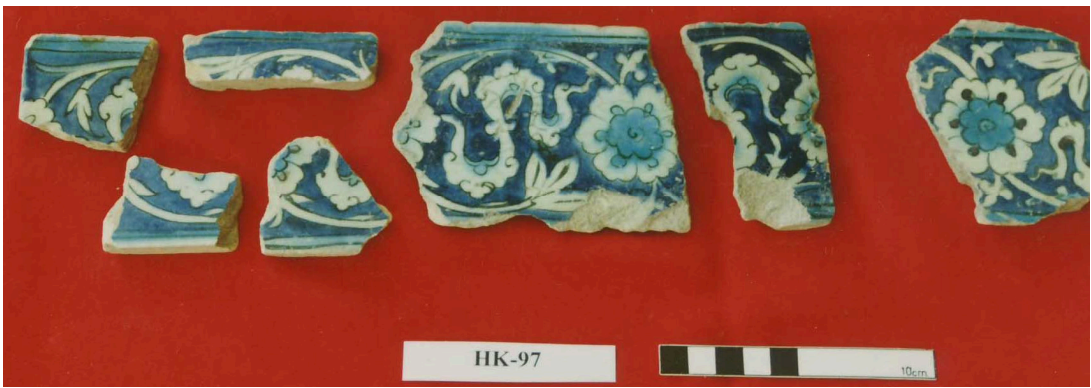

(Mercan, 2001).

Aynı dönemin bir başka özelliğini yansıtan mercan kırmızısı, mavi ve lacivert renkler siyah konturlerle belirlenerek uygulanmıştır. Kompozisyonlarda realist lale, karanfil, gül goncası, sümbül, iri kıvrık dişli yapraklar, iri sülüs harfler görülmektedir. Daha sonraki döneme ait bazı çini parçalarında çintemani veya pars beneği motifi, şakayık, Çin bulutu motifleri etkilerini göstermektedir. Bir başka değişik formdaki çini parçası, üç parça halinde bulunan mavi beyaz zemin üzerine işlenmiş kompozisyonlardır. Çini parçasında hatai çiçeği ve bunun merkezinde simetrik olarak bulut motifi vardır. Hatâi motifini çevreleyen eşit aralıklarda taç yaprakları görülmektedir (Mercan, 2001, s. 69,70; Belli, 2009, s. 34-62).

\section{Görsel 24}

Hüsrev Paşa Camii Hatai Çiçek Motif Görünüşleri

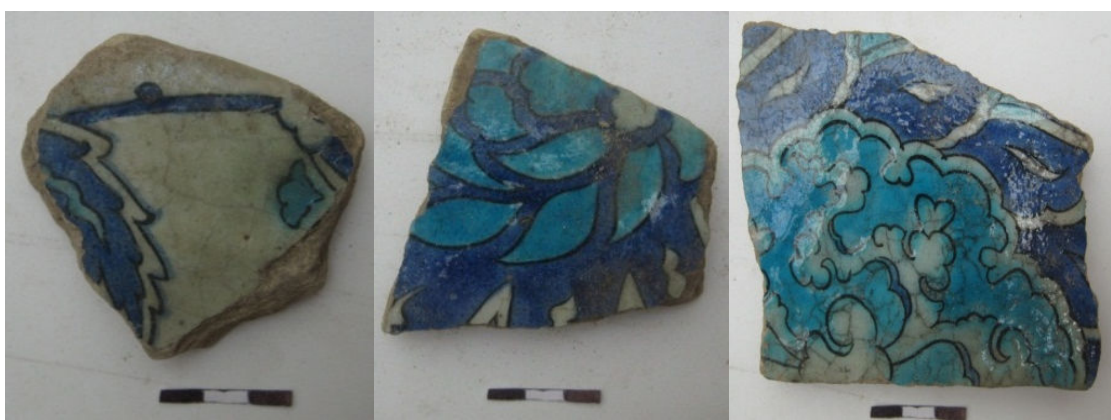

(Mercan, 2001).

Hatai çiçeğinin uçlarından çıkan dalların uçlarında penç çiçeği görülmektedir. Hatai çiçeğinin etrafındaki mavi zemin üzerine işlenmiş siyah konturlerle belirlenmiş gonca gül motifi mevcuttur. Bir başka çini parçası üzerinde; iki yatay dalgalı çizginin altında ve üstünde toplam üç yuvarlak benek yer almaktadır. 


\section{Görsel 25}

Hüsrev Paşa Camii Duvar Yüzeylerini Temizlik Görünüşleri

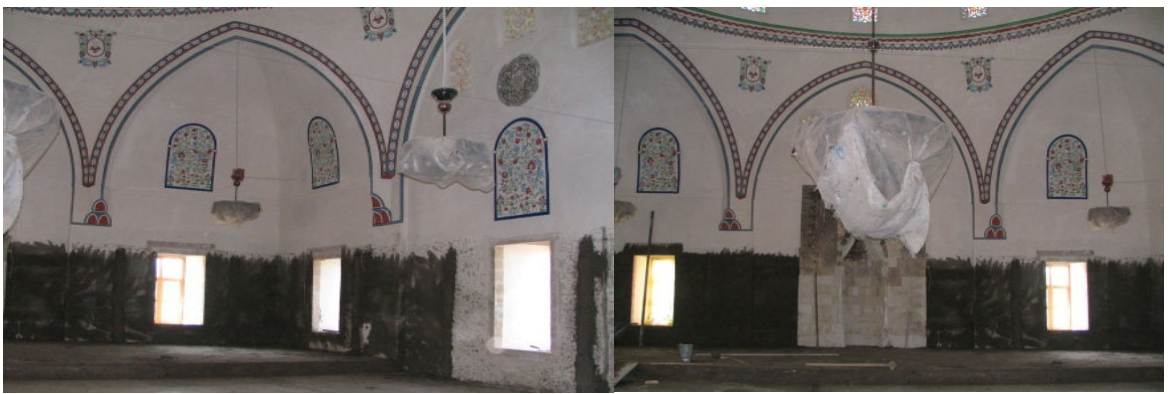

(Öztürk, t.y.).

Çintemani motiflerinin her iki yanlarına üç benek ve motiflerin aralarında stilize yapraklar bulunur. Çininin altında bir sıra palmet motifi yer alır. Kullanılan renler siyah konturler içinde mavi-beyaz zemin üzerine mercan kırmızısı ve yeşildir (Mercan, 2001, s. 69; Belli, 2009, s. 34-62). Hâkim renk olarak mavinin üzerine simetrik stilize rumi motifli desenler görülür. Çininin merkezinde bulunan penç çiçeği ile ruminin uçları birleşmekte ve Rumilerin genel olarak oluşturduğu kompozisyon palmet motifi ve bunun aralarında küçük penç çiçekleri gözlenir (Görsel 21-25).

\section{Görsel 26}

Hüsrev Paşa Camii Çini Kaplama Uygulama Görünüşleri

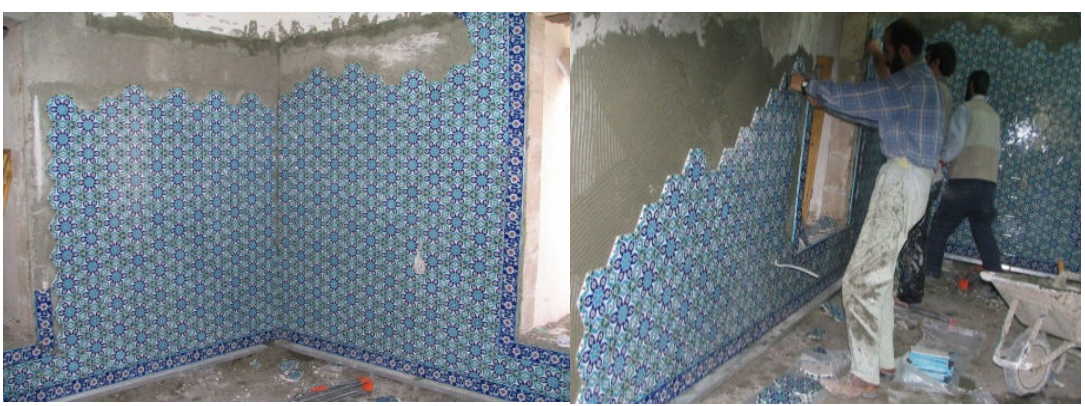

(Öztürk, t.y.).

Kazılarda ortaya çıkan üç parça halinde bulunan kare panolu altıgen çini levhalar, aynı dönemin üslubunu yansıtmaktadır. Natüralist üsluptaki pano; beyaz zemin üzerinde, lale, karanfil, hatâi ve narçiçeği yer almakta ve kompozisyonun genelinde ince dallar bulunmaktadır. Kullanılan renkler siyah konturler içerisinde lacivert, mavi, yeşil, mercan kırmızısıdır. Kompozisyonun merkezindeki lalenin ortasından ince bir dal geçmektedir. Lalenin solunda narçiçeği bulunmaktadır. Ayrıca çini levhadaki en büyük kompozisyonun lale olduğu görülmektedir (Mercan, 2001, s. 68,69).

\section{Görsel 27}

Hüsrev Paşa Camii İç Mekan Görünüşleri

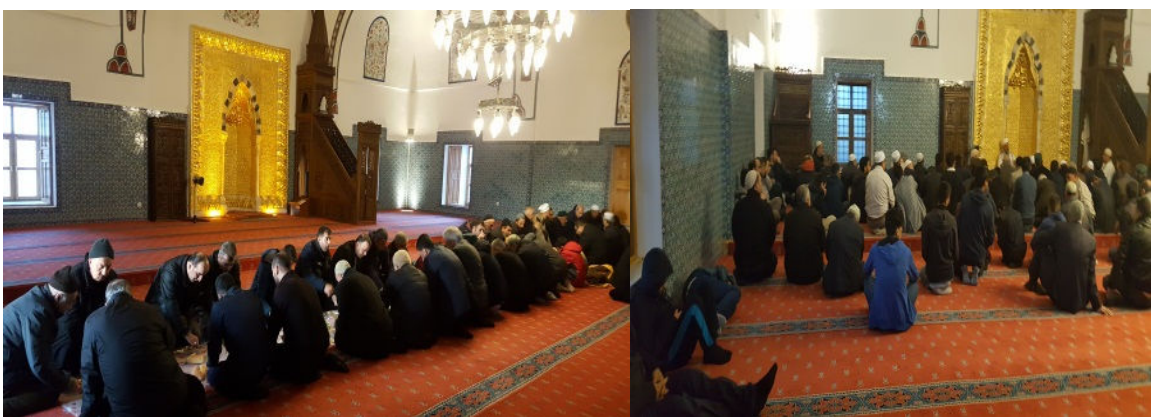

(Öztürk, t.y.).

Kazılarda ortaya çıkan küçük parçalı çiniler beyaz zemin üzerine altı kollu yıldız kompozisyonuyla süslenmiştir. Genellikle lacivert, mavi renkler kullanılmıştır. Altı kolu yıldızın merkezinde altı yapraklı stilize çiçek uygulanmıştır. Altıgen çinilerin kenar bordürlerini dikdörtgen formu çiniler tamamlamaktadır. Lacivert zemin üzerine beyaz hatai çiçeği bulunmaktadır. Çini bezeme içerisinde hafif kıvrımlı bulut motifi ve bunu alttan ve 
üsten çevreleyen hatai çiçeğinden çıkmış dallar yer almaktadır. Dalların uçlarındaki yapraklar yeşil ile belirtilmiş ve tüm çini siyah kontürle renklendirilmiştir.

Cami beden duvarları içten zeminden $2.37 \mathrm{~m}$. yüksekliğe kadar pencere üzerlerinde $0.30 \mathrm{~m}$. kademe olacak şekilde özgün çini örneklerinde oluşan çini kaplaması tamamlanmıştır. Kazı sonucunda ortaya çıkan çini örnekleri ile Van Müze depolarında bulunan orijinal çini form ve desenlerinin çizimleri yapılmıştır. Hazırlanan çini modeli ve örnekleri İznik’teki geleneksel çini üretim laboratuvarlarında analizleri uzman bilim insanlarının gözetiminde yapılarak hazırlanan çini kalıpları el ile tek tek çizilerek özgün çini üretimi yapılmıştır. Dikdörtgen formundaki çiniler zemin ve üst çerçevede bir bant şeklinde kullanılmıştır (Öztürk, 2020b, s.1237-1268; Mercan, 2001, s. 68).

\section{Görsel 28}

Hüsrev Paşa Camii Mihrap Onarım Öncesi Görünüşleri
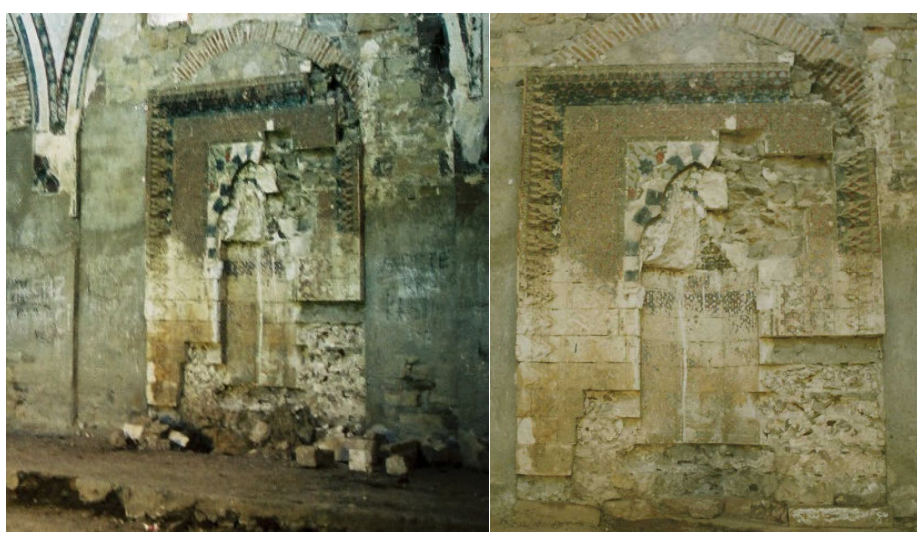

(Öztürk, t.y.).

Uygulama yapılan cami beden duvarlarının onarımı yapıldıktan sonra duvarlar yatay ve düşeyde şakulüne teraziye getirilerek uygulama çalışması konusunda uzman sertifikalı kalifiye ustalar tarafından tamamlanmıştır (Görsel 21-27).

\subsection{Taș Süsleme}

Hüsrev Paşa Külliyesi'nde geometrik taş süsleme ağırlıklı olarak cami ve kümbet yapısında kullanılmıştır. Diğer tamamlayıcı külliye bölümleri daha çok sade ve yalın bir tarzda inşa edilmiştir. Caminin mihrap, giriş kapısı, minare ve pencerelerde çeşitli geometrik taş motifli süslemeler kullanılmıştır.

\section{Görsel 29}

Hüsrev Paşa Camii Mihrap Mührü Süleyman, Özgün Altın Varak Görünüşü

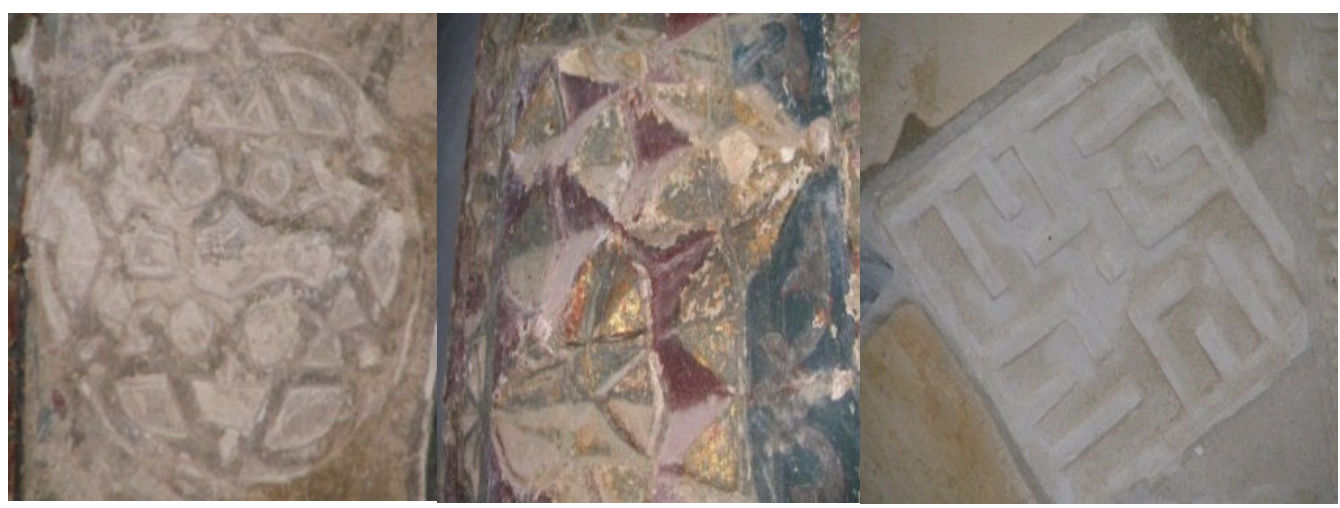

(Öztürk, t.y.).

Giriş kapısının merkez aksı doğrultusunda güney beden duvarının ortasında $0.10 \mathrm{~m}$. içe taşıntılı 2.26x3.97 m. ölçülerinde altın varaklı zengin dekoratif mukarnas süslemeli mihrap nişi bulunur. Mihrap, güney beden duvarından $0.74 \mathrm{~m}$. dişa taşıntılıdır. Mihap nişi, 1.06 genişlikte $0.65 \mathrm{~m}$. derinlikte beş kenarlı köşelerde sütünceler yardımıyla iki dilimli sivri kemer ile çevrelenmiştir (Görsel 28-30). Mihrap kalker taşından yapıılmış, taşlar oyma tekniğinde süslenmiştir. Beşgen nişin içerisi altı kollu yıldızlarla doldurulmuştur. Üstten üç dilimli kemerle kuşatılmış, mukarnaslı bir kavsarayla sonlanmıştır. İçteki bordürde sekizgen geçmeler ve ortalarına gülbezekler yapılmıştır. Dıştakinde ise, mukarnas dizisinden oluşan bir bordür yer almaktadır. 


\section{Görsel 30}

Hüsrev Paşa Camii Mihrap Süsleme Detayları

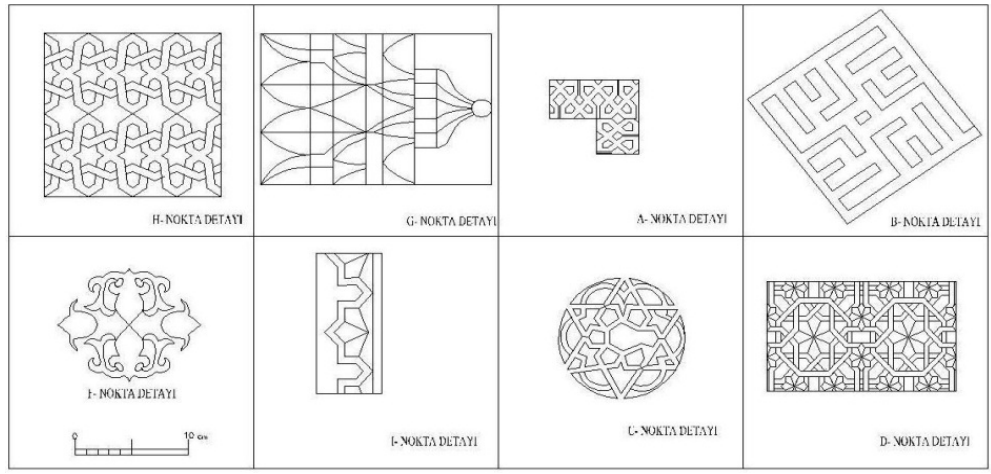

(Öztürk, t.y.).

Yapılan temizlik çalışmalarında mihrap üç dilimli kemerin üst alınlık yüzeyinde her iki yanında kare formunda üste simetrik Satrançlı Kufi ile dört adet "Allah" yazılı motif ile alt kısımda ise yuvarlak formunda kabartılı oyma taş işçiliği ile bezeli “Mühr-ü Süleyman” süsleme motifleri ortaya çıkarılmıştır.

\section{Görsel 31}

Hüsrev Paşa Camii Mihrap Uygulama Görünüşleri

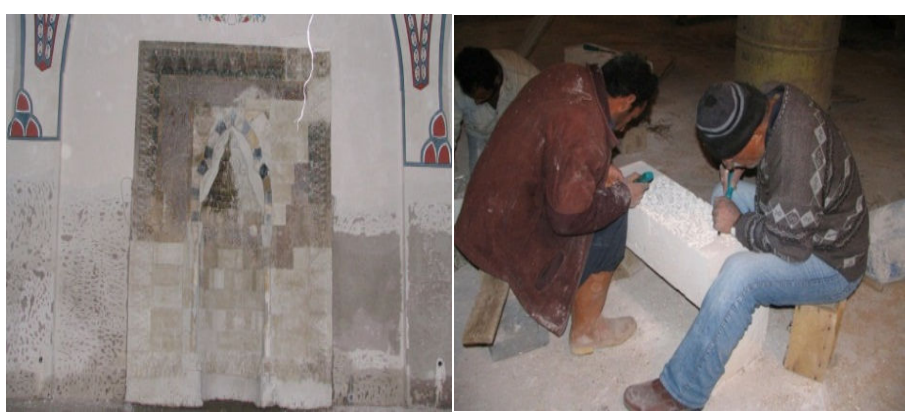

(Öztürk, t.y.).

Mihrap nişinin tüm yüzeyi alttan ve üstten eşkenar dörtgen iki şeritle sınırlandırılmış, altı kollu yıldızlarla süslenmiştir. Mihrabı en diştan, alttan da dolanarak oturtmalık teşkil eden mukanaslı bir bordur çevrelemektedir (Öztürk, 2020, s. 1237-1268). İçten ve dıştan düğüm motifli ince şeritlerle sınırlandırılmış ana bordur, sekizgenlerden gelişen geometrik geçme motiflerinden oluşan kompozisyonla bezenmiştir. Kavsarayı dolduran mukarnasların tamamı yakın dönem define arayıcıları tarafından kazınarak tahrip edilmiştir (Görsel 31-33). Vakıflar Genel Müdürlüğü tarafından mihrap yüzeyinde alınan örnek numuneleri laboratuvarlarda analizleri sonucunda yüzeyin orijinalde altın varaklı bir kaplama tespit edilmiştir. Bu amaçla mihrap yüzeyi ile giriş kapısı kitabeli bölümü altın varak uygulaması yapılmıştır (Görsel 32-33).

\section{Görsel 32}

Hüsrev Paşa Camii Mihrap Plan, Kesit, Cephe Detay Çizimleri
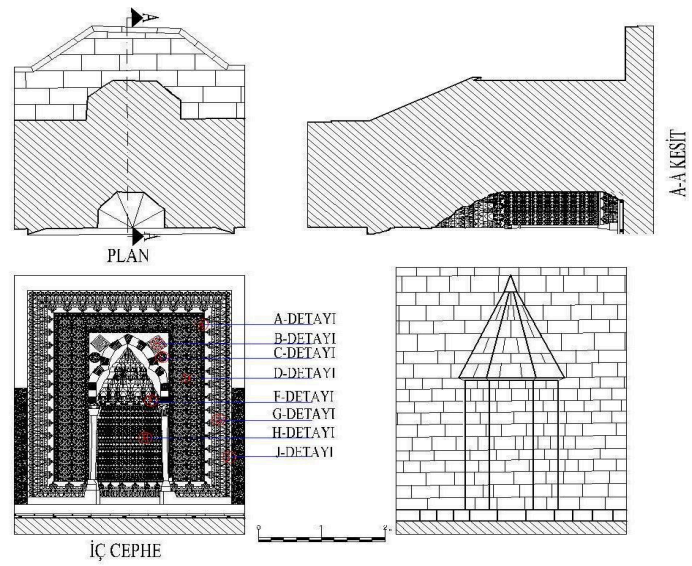

(Öztürk, t.y.). 


\section{Görsel 33}

Hüsrev Paşa Camii Mihrap Genel Görünüşü

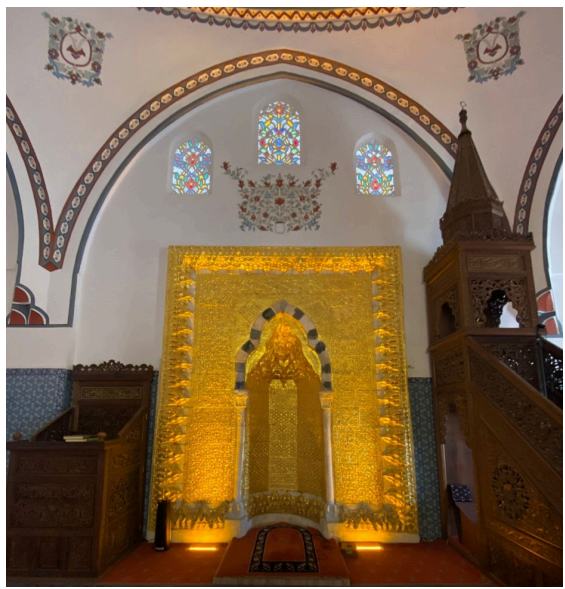

(Öztürk, t.y.).

Caminin kuzeybatı köşesinde kare bir kaide üzerinde yükselen minarenin kürsü kısmının kuzey, batı ve güney cephelerinde Satrançlı Kufi yazılar bezenmiștir. Peşinden gelen taş sırasından sonra kaş kemerler yüzeyi hafifçe oyulmuş olarak üç yönde bir ters bir düz olarak dolanmaktadır. Gövdeye geçişteki pahların üst kısımlarında stilize hurma dalları yer almaktadır.

\section{Görsel 34}

Hüsrev Paşa Camii Minare ve Süsleme Detayları
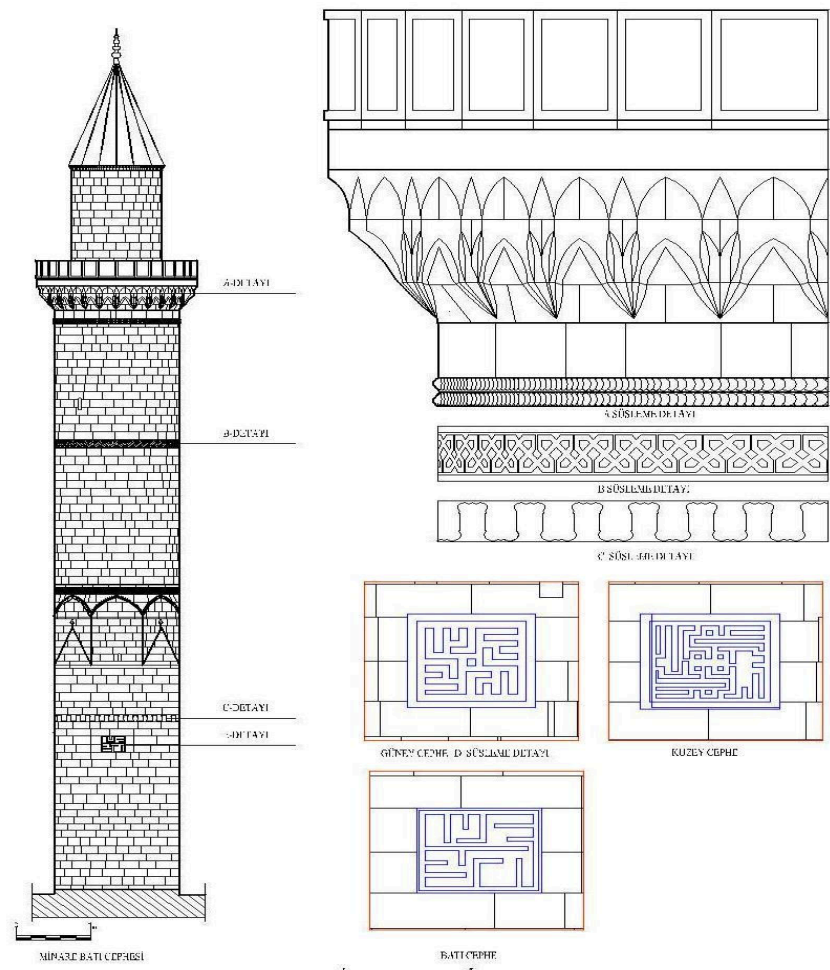

(Öztürk, t.y.).

Pahlardan sonra sekizgen prizma şeklinde pabuç kısmı gelmektedir. Silindirik gövdenin başladığı yerde burmalı iki kuşak yer almaktadır. Gövdenin ortasında iki çift silmenin sınırladığı kuşağın yüzeyi birbirine geçmeli "S" motifi ile tezyin edilmiştir. Gövdenin bitiş kısmına yakın yerde çift burmalı silme, bir taş sıra sonrası mukarnaslı şerefe gelmektedir. Şerefe korkulukları taş levhalarla oluşturulmuştur (Görsel 34-35). 


\section{Görsel 35}

Hüsrev Paşa Camii Minare Kitabe Görünüşleri

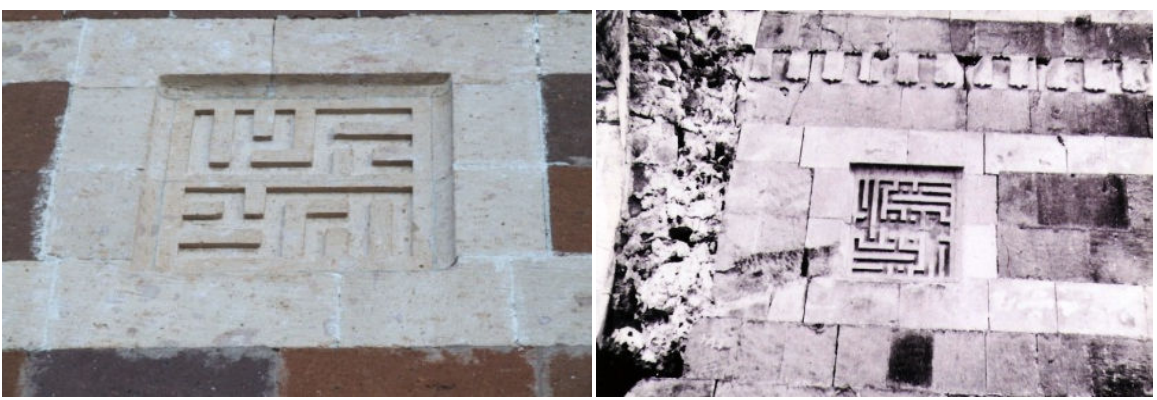

(Öztürk, t.y.).

Cami giriş kapısının sivri kemer nişi içerisinde $0.44 \times 1.67 \mathrm{~m}$. ölçülerindeki yekpare kitabeliğin çevresi taş süslemeli olarak bezelidir. Kitabeliğin oturduğu kapı lento taşı ise $0.28 \times 1.47 \mathrm{~m}$ ölçülerindedir. Yekpare kalker taşından imal edilmiş lento taşı üzerinde yer alan dört adet simetrik 10 kollu yıldızın çevresi geometrik süsleme motifi ile bezelidir.

\section{Görsel 36}

Hüsrev Paşa Camii Giriş Kapısı Plan, Kesit ve Cephesi

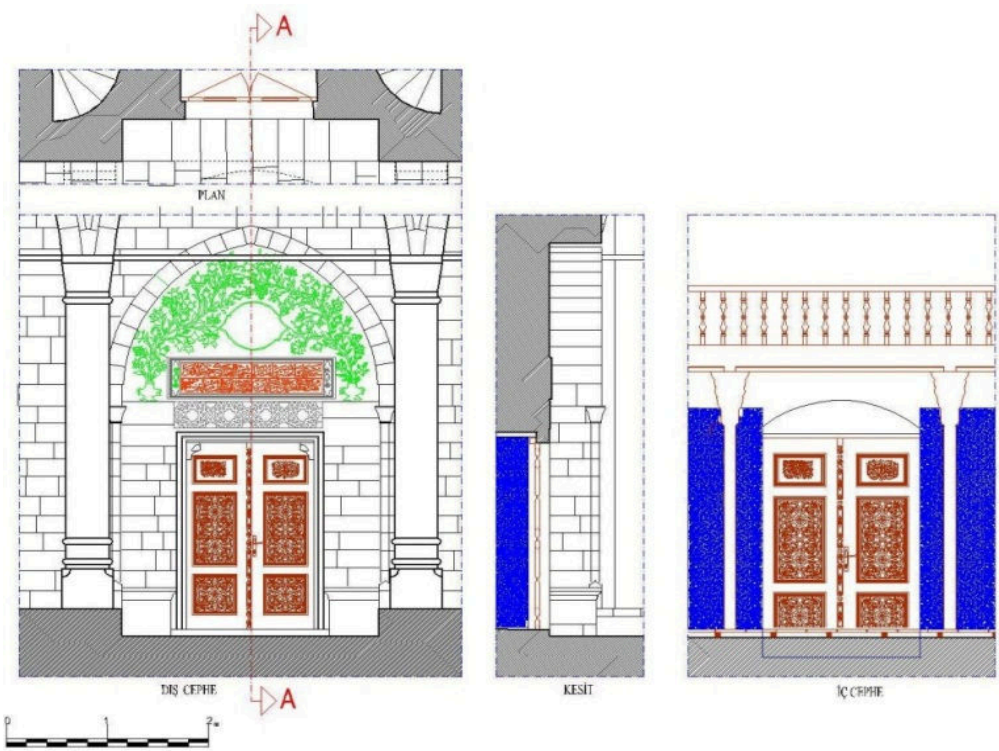

(Öztürk, t.y.).

Kapı sivri kemer üzengisinin oturduğu sütünce başlıkları ise geometrik süsleme ile donatılmıştır. Son cemaat bölümünde yer alan sutun alt ve üst kısımlarında pah ve taştan yuvarlak bilezikler yer almaktadır (Görsel 36-37).

\section{Görsel 37}

Hüsrev Paşa Camii Kitabe Süsleme Detayı

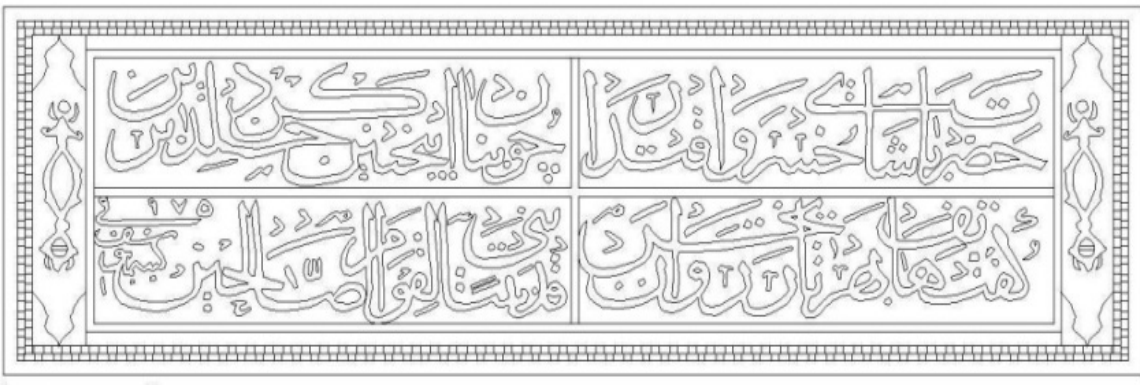

(Öztürk, t.y.). 


\section{Kitabenin Okunuşu}

"Hazret-i Paşa-ı Hüsrev iktidar Çün bina inçünin kerd huld-i berrin Güft hatif behar târıheş ruvat Kâd bena beyten li-kavm-is salıhin Ketebe Yusuffi 975",

\section{Kitabenin Anlamı}

“İktidar sahibi Hüsrev Paşa Hazretleri baki ve yüce rabbin rızası için bina etti Hafiften gelen tarihi için şöyle dediler "Salihler topluluğu için bir ev (mescid) inşa etti" Yusuf yazdı tarih 975 (1567-68)" ifadeleri yer almaktadır.

\section{Görsel 38}

Hüsrev Paşa Camii Giriş Kapı Süsleme Detayı

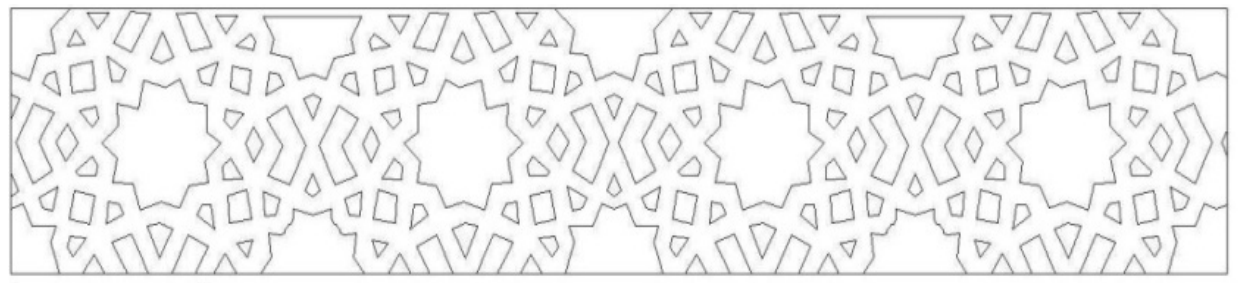

(Öztürk, t.y.).

Caminin cephelerinden karşılıklı olarak aynı yatay kot üzerinde doğu ve batıda üçer, kuzey ve güneyde ise ikişer toplam 10 adet pencereler yer almaktadır. Benzer mimari özelliklerde sivri kemer nişi içerisinde dikdörtgen formlu pencerelerin üzerinde tek ve iki sıra halinde mukarnas motifleri bulunur. Pencere sivri kemerleri iki renkli (beyaz-kahverengi) taş kullanılarak yapılmıştır. Kemer pencere köşelerinde yuvarlak sütunce oturmaktadır. Pencere atkı taşı yekpare üzerinde sıralı taşlar binili olarak inşa edilmiştir (Öztürk, 2020, s. 1237 1268), (Görsel 38-40).

\section{Görsel 39}

Hüsrev Paşa Camii Pencere Mukarnas Detaylarl

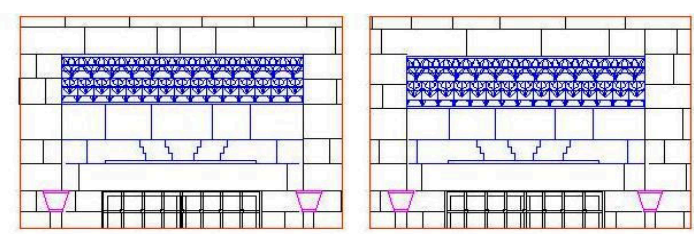

KUZEY CEPIIE
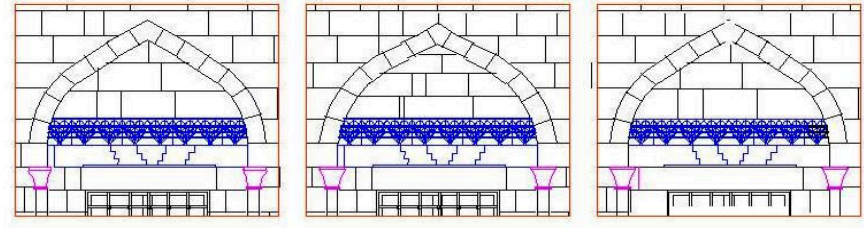

DOĜL CEPIIE

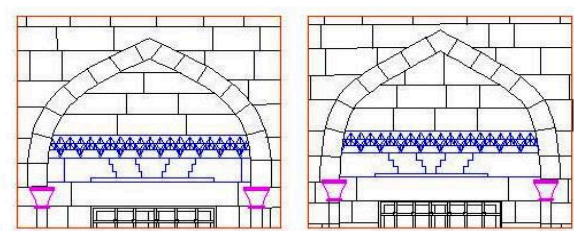

GÜNEY CEPHE
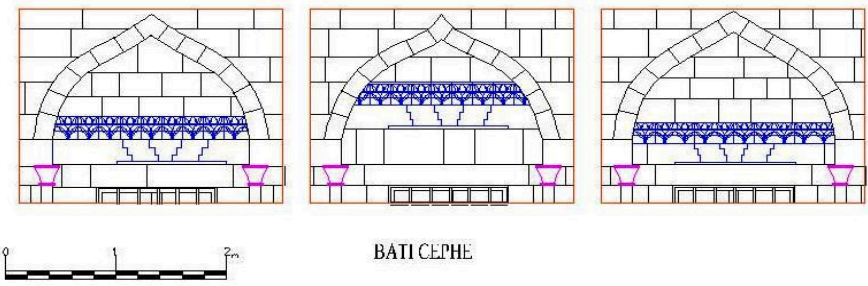

BATI CEPHE

(Öztürk, t.y.). 


\section{Görsel 40}

Hüsrev Paşa Camii Pencere Mükarnas Süsleme Görünüşleri

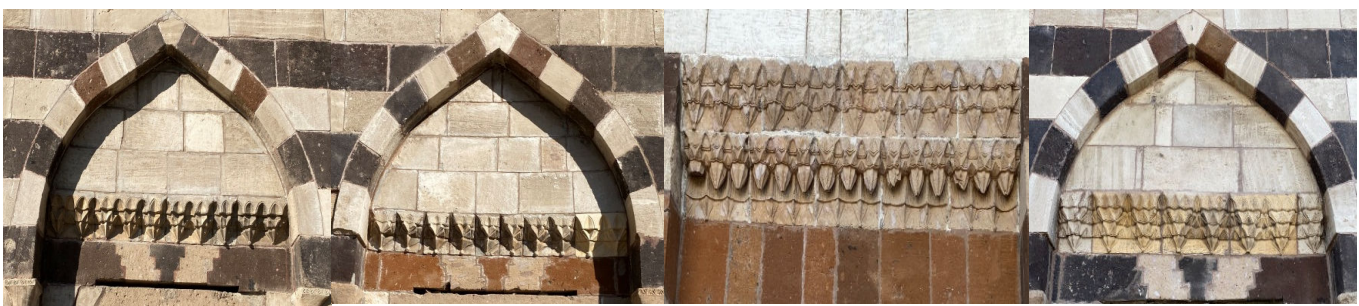

(Öztürk, t.y.).

Caminin hemen doğusunda yer alan Hüsrev Paşa Kümbeti özellikle giriş kapı üç dilimli sivri kemer üzerinde ve alınlığında taş işlemeli geometrik, bitkisel ve kitabe süslemeli motifler vardır. Kümbetin tüm cepheleri genel olarak simetrik görselde tasarlanmıştır. Zeminde üç yatay sıra şeklinde devam eden $0.25 \mathrm{~m}$. kalınlığındaki mukarnas bezeme üzeri $0.30 \mathrm{~m}$. kesme duvar şeklinde yükselerek, $0.05 \mathrm{~m}$ dışa taşkın çift burgulu süsleme yer almaktadır. Her cephe ortasında bulunan $1.67 \mathrm{~m}$. genişliğindeki pencere açıklığı her iki yanda yuvarlak sutunceler üzerindeki geometrik bezemeli sütünce başlıkları üzerinde yer alan iki dilimli sivri kemerden oluşmaktadır (Öztürk, 2020, s.1237-1268).

\section{Görsel 41}

Hüsrev Paşa Kümbeti Kitabe Süsleme Görünüşleri

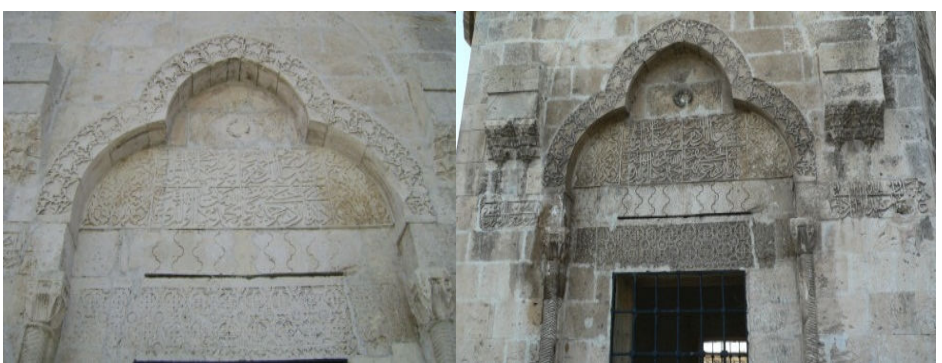

(Öztürk, t.y.).

Pencere açıklığı her iki yandan $0.37 \mathrm{~m}$. genişliğinde ve $0.25 \mathrm{~m}$. derinliğinde daralarak oluşan dikdörtgen formlu pencere $0.92 \times 1.70 \mathrm{~m}$. ölçülerindedir. Pencere açıklığ 1 üzeri dekoratif bezemeli $0.30 \mathrm{~m}$. kalınlığındaki bir atkı taşı yerleştirilmiştir. Her cephedeki pencere atkı taşı üzerindeki dekoratif bezeme birbirinde farklı olarak süsleme kullanılmıştır. Pencere atkı taşı üzerinde yer alan iki düz kademeli $0.25 \mathrm{~m}$. kalınlığında kilit taşı arasında ise 0.02 m. kalınlıkta $0.87 \mathrm{~m}$. genişlikte bir basınç boşluğu bulunmaktadır. Pencere kilit taşı üzerinde yatay bir sıra halinde devam eden mukarnas süsleme frizi yerleştirilmiştir. Üç dilimli kemer üzerinde $0.45 \mathrm{~m}$. genişliğinde yuvarlak kemerli küçük bir pencere bulunur (Görsel 41-42).

\section{Görsel 42}

Hüsrev Paşa Kümbeti Süsleme Detaylarl
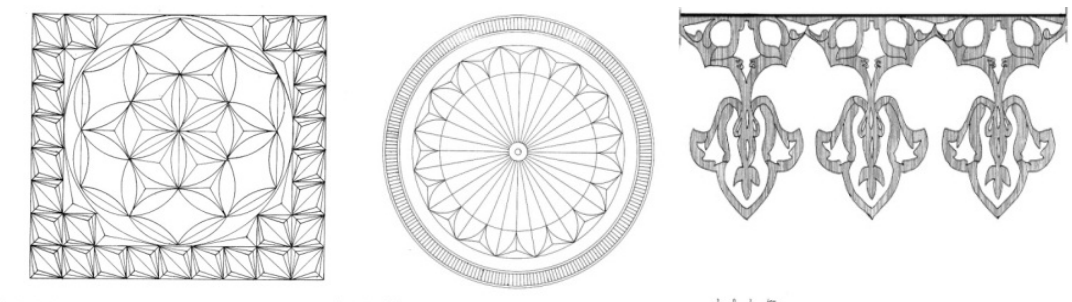

(Öztürk, t.y.).

Yuvarlak pencere üzerinde şerit halinde devam eden kabartmalı palmet motifi ile sonuçlanan cephe, zeminden 5.64 m. yükselerek, iç bükey bir saçak yardımıyla piramidal külaha geçiş yapmaktadır. Kümbetin giriş kapısı diğer beş cephedeki ölçülere göre oldukça zengin süslemeler ile donatılıdır. Kapının kuşatma kemeri üzerine palmet motifleri işlenmiştir. Kemer alınlığının ortasında yer alan iki beyitlik dört simetrik kartuşlu 0.50x 0.86 m. ölçülerindeki girift sülüs kitabenin her iki yanı girift süslemelidir. Kitabenin üstünde yer alan bitkisel süslemeli taşın ortasında oldukça tahrip olan bir rozet yerleştirilmiştir. Bu süslemeli taşın üstündeki taşta ise altı köşeli süslemeli yıldızın ortasında bir gül motifi yer almaktadır (Görsel 43). 


\section{Görsel 43}

Hüsrev Paşa Kümbeti Kitabe Süsleme Detayları
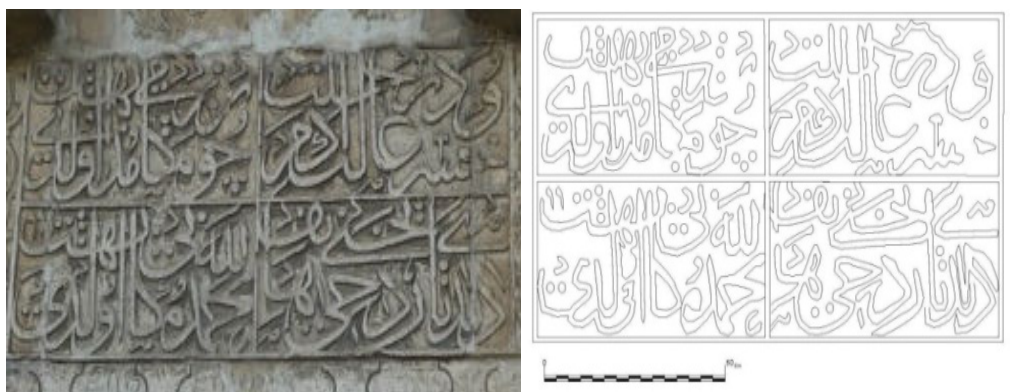

(Öztürk, t.y.)

\section{Kitabenin Okunuşu}

Hüsev

Çün mekân-ı müdeami oldu bihişt

Dedi tarihini dahi Hatif

Hamdülillah mekânı oldu bihișt"

\section{Kitabenin Anlamı}

“Hüsrev.....

Isteği yerine getirilerek cennete çevrildi.

Tarihi Hatif düsürdü,

Allaha hamd olsun mekânı cennet oldu”"

Kitabede ebcet hesabıyla H. 996 (M.1587-88) kümbet inşa tarihi yazılmıştır (Talay, 1988, s. 164,165; Kılıç, 1997, s. 233; Günel, 1993, s. 67,68; Eyice, 1999, s. 51). Giriş kapısının üç dilimli kemer üzengi seviyesinin her iki yanında simetrik olarak yerleştirilen $0.25 \times 0.45 \mathrm{~m}$. ölçülerinde iki kitabe yer almaktadır.

\section{Kitabenin Okunuşu}

“El Mü-minü hayyün fi'd-dâreyn”,

\section{Kitabenin Anlamı}

"Mümin iki dünyada da diridir"

Her iki kitabenin üst bölümünde mükarnas süslemeli dışa taşıntılı simetrik iki konsol yerleştirilmiştir.

\section{Görsel 44}

Hüsrev Paşa Kümbeti Giriş Kapısı Kemer Alınlık Cephe Süsleme Görünüşleri

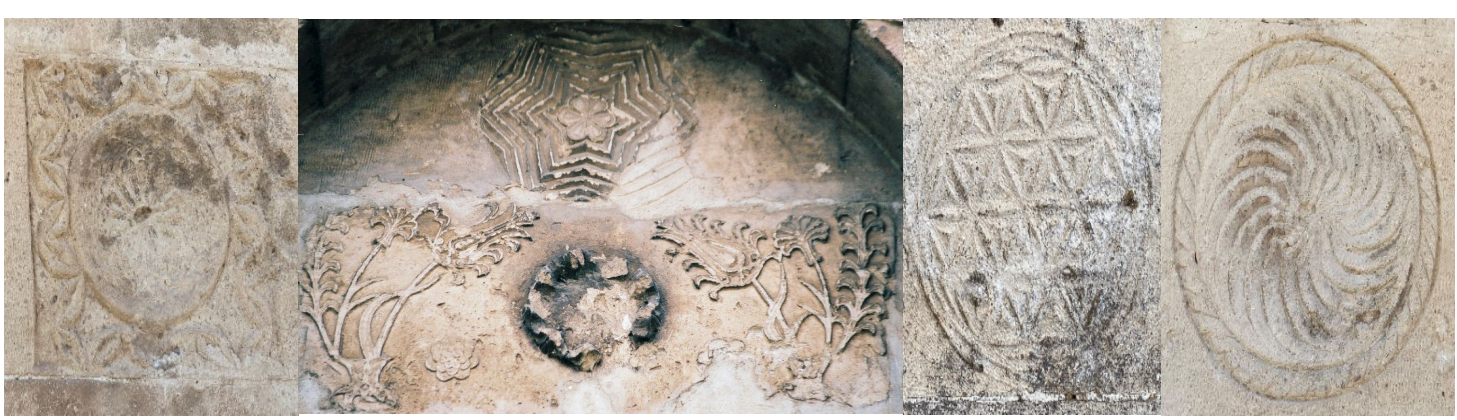

(Öztürk, t.y.).

Cami ve kümbetin çeşitli bölgelerinde yer alan taş süslemeler doğal findık, ceviz kabuğu ve dolomit malzeme ile basınçlı püskürtme ile temizlik yapılmıştır. Cepheler ve örtü sisteminin bakım ve onarımları yeniden yapılarak, bazı bölümlerde yıpranan ve özelliğini yitiren yonu taşlar raspa işlemi sonucunda yeniden onarılmıştır (Görsel 44-45). 


\section{Görsel 45}

Hüsrev Paşa Kümbeti Onarım Temizlik Görünüşleri

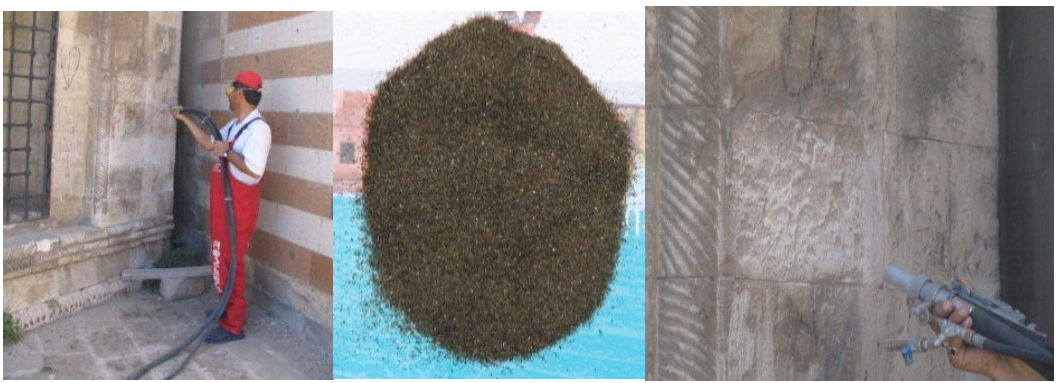

(Öztürk, t.y.).

\subsection{Ahșap Süsleme}

Hüsrev Paşa Külliyesi’nde yer alan tüm yapıların özgün ahşap yapı elemanları ve doğramaları 1915-80 yıllar arasında yaşanan olumsuzluklar sonucunda yok olmuştur. Külliyenin merkezinde yer alan cami 1967, 1996, 2002, 2007-08 ve 2012-13 yıllar arasındaki Bitlis Vakıflar Bölge Müdürlüğü onarımlarında özgün ahşap malzemenin olmadığı bilinmektedir (Öztürk, 2020, s. 1237-1268).

\section{Görsel 46}

Hüsrev Paşa Camii Mihrap Plan ve Detaylart

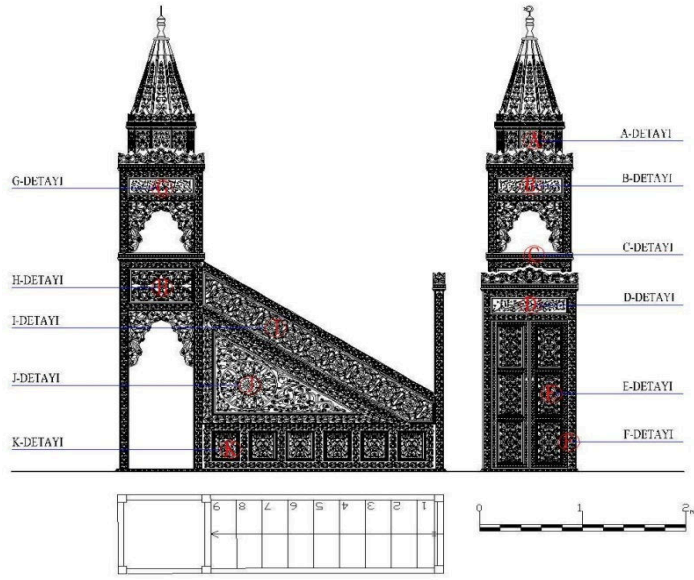

(Öztürk, t.y.).

Cami kapısı, minber, kürsü ve kitaplık bölümleri ceviz ağacı ile üretilen doğramaları bitkisel, geometrik ve yazı süslemelerinin kullanılmasına, Vakıflar Genel ve Bölge Müdürlük süsleme uzman elemanları gözetiminde Kahramanmaraş ilinde geleneksel el ahşap oyma işçiliği ile hazırlanmıştır. Hazırlanan minber, kapı, kürsü, kitaplık Van Kültür Varlıkları Bölge Koruma Kurul tarafından onaylanarak yeniden yapılmıştır. Ceviz doğrama kullanılarak hazırlanan minber, 0.90x3.15 m. ölçülerinde dikdörtgen planlı bir kaide üzerinde $5.38 \mathrm{~m}$. yükselerek tasarlanmıştır. Minberin her iki yan ve giriş kısmı simetrik yuvarlak, kare ve dikdörtgen panolar içerisinde simetrik olarak geometrik, bitkisel ve hat sanatı ile donatılmıştır.

\section{Görsel 47}

Hüsrev Paşa Camii Minber Çizim Detaylarl ve Görünüşleri
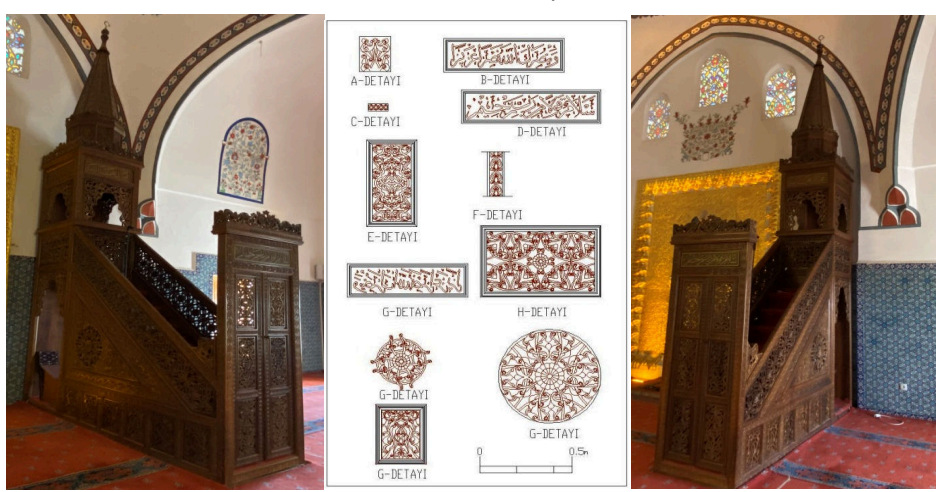

(Öztürk, t.y.). 
Caminin tüm pencere doğramaları içten çift kanatlı, dıştan ahşap kayıtlı olarak ve taban zemin ahşap rabıta olarak yapılmıştır. Giriş kapısı, minber, kürsü ve kitaplık ceviz doğramalı Kahramanmaraşlı ahşap ustalar tarafından geleneksel bezeme motifli olarak hazırlanmıştır (Görsel 46-48). Kitaplık cami iç mekanının güneydoğu köşesinde yer alır. Çeviz ağacından imal edilmiş kitaplık 0.30x0.85x2.15 m. ölçülerinde dikdörtgen planlı iki kapaktan oluşmaktadır. Kitaplık kapak kanatları simetrik olarak tasarlanmış üçer dikdörgen kayıtlar içerisinde simetrik bitkisel motifler ile oyma ahşap tekniği ile işlenmiştir (Öztürk, 2020, s.1237-1268), (Görsel 48).

\section{Görsel 48}

Hüsrev Paşa Camii Dolap Çizim Detayları ve Görünüşü
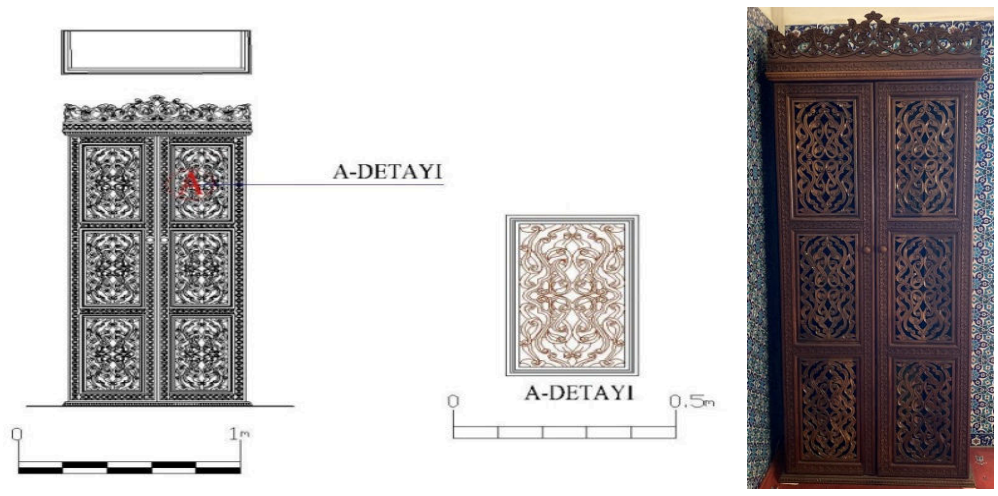

(Öztürk, t.y.).

2007-13 yılları arasında külliyenin, cami dışında medrese, imaret, kümbet ve şadırvan onarımlarında herhangi bir ahşap süsleme unsuru kullanılmamış, tüm ahşap doğramalarında yalın olarak tercih edilmiştir. Kürsü, 1.10x1.10 m. ölçülerinde kare kaide üzerinde $2.50 \mathrm{~m}$. yükselerek tasarlanmıștır. Kürsünün her iki yan ve ön kısmı yuvarlak, kare ve dikdörtgen panolar içerisinde simetrik olarak geometrik, bitkisel ve hat sanatı ile donatılmıştır (Görsel 49).

\section{Görsel 49}

Hüsrev Paşa Camii Kürsü Görünüş ve Çizim Detaylarl
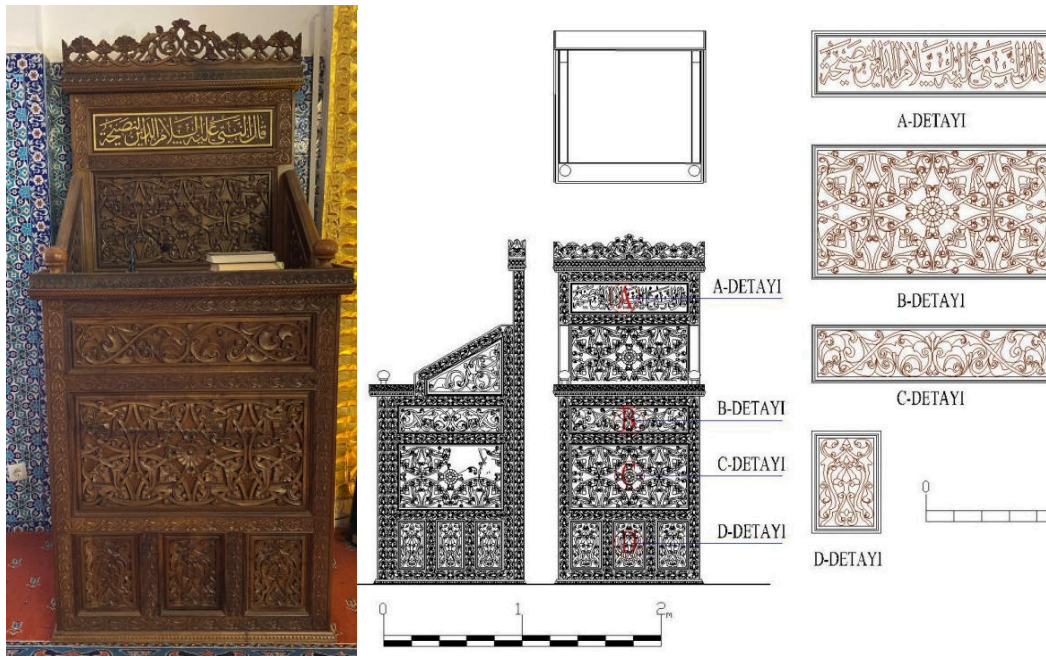

B.DETAYI

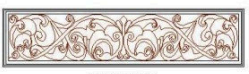

C.DETAYI

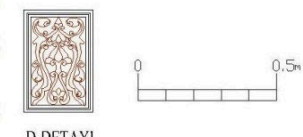

(Öztürk, t.y.).

Cami giriş kapısı 1.46x2.09 m. ölçülerinde dikdörtgen çift kanatlı ceviz doğramalı ve dekoratif süslemeli bir yapıya sahiptir. Simetrik olarak iç ve dıştan tasarlanmış kapı kanatları üzerindeki toplam 12 adet pano içerisinde bitkisel, geometrik ve hat sanatı ile bezeli motifler ile donatılıdır (Görsel 50-51). Cami iç mekânında yer alan ahșap doğramalı mahfil, korkuluk, pencere, kümbet kapı ve pencere, minare kapı, şadırvan tavan kaplamasında ve son cemaat ahşap saçağı son derece yalın olup herhangi bir süslemeye rastlanmamıştır (Öztürk, 2020, 182209). 
Görsel 50

Hüsrev Paşa Camii Giriş Kapı Çizim Detayları

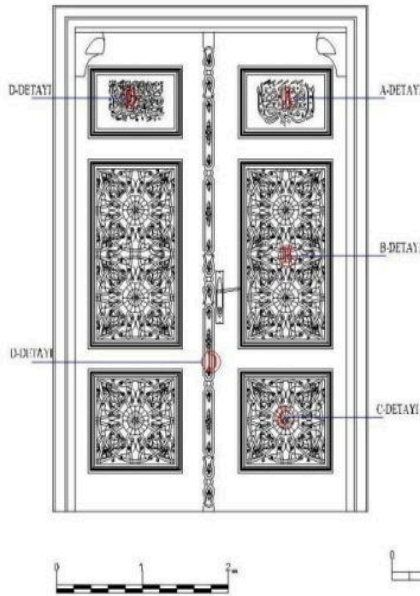

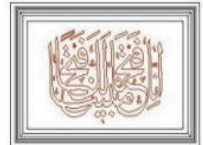

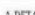
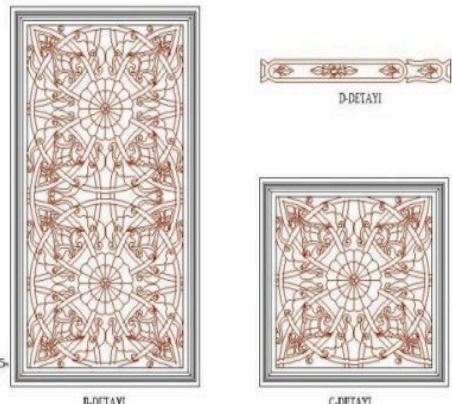

(Öztürk, t.y.).

\section{Görsel 51}

Hüsrev Paşa Camii Giriş Kapı Görünüşü

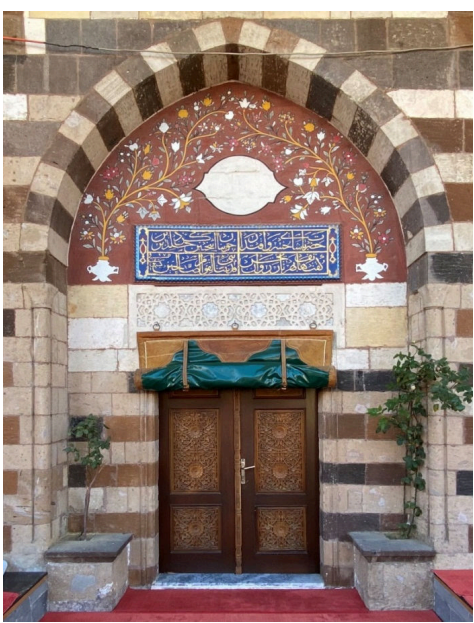

(Öztürk, t.y.).

\section{Sonuc}

Eski Van Şehri ve Kalesi’nin konum ve stratejik yapısından dolayı, geçmişte birçok uygarlık tarafından kullanılmıştır. Her uygarlık dini, askeri ve sivil mimarlık eserleri ile kadim olan șehri adeta mimari yapılar ile donatmıştır. Kuşkusuz bu önemli kente hayat veren dini mimari yapılar içerisinde Hüsrev Paşa Külliyesi'nin önemli bir yer vardır. Osmanlı klasik dönem mimari özelliğinden inşa edilen külliye içerisinde yer alan cami ve kümbette kullanılan mimari süsleme oldukça önem arz etmektedir.

Kalem işi, çini, taş ve ahşap süslemede oluşan süsleme içerisinde cami ve kümbette kullanılan taş süsleme özgün ve hiçbir mimari değişime uğramadan günümüze kadar gelmeyi başarmıştır. Caminin giriş kapı alınlığında, mihrapta, kemer, tromp ve duvar satıhlarında panolar içerisinde kullanılan kalem işi süsleme geç dönem Barok tarzı süsleme motiflerden oluşmaktadır. Külliyede özgün ahşap süsleme ve doğrama örnekler günümüze kadar ulaşamamıştır. Son dönem onarımlarda kullanılan ceviz ahşap mimari süslemeler ise dönem mimari özelliğini yansıtmaktadır. Camide kullanılan altıgen ve dikdörtgen formundaki çinilerin bir bölümü Van Müzesi’ndeki örnekler alınarak çini onarımında oldukça önem taşımış ve kullanılmıştır.

Külliyenin onarım sonrası önemi kutsal dini günlerde birçok yerli ve yabancı turist tarafından ziyaret ya da ibadet amaçlı olarak kullanılmaktadır. Külliyenin tamamlayıcı mekânlarından olan, cami, imaret, kümbet, avlu, şadırvan ve medresenin onarımları yapılarak yöre halkının hizmetine sunulmuștur. Osmanlı Devleti'nin Anadolu'nun en doğudaki eseri olan Hüsrev Paşa Külliyesi klasik dönemde mimari özelliklerine sahiptir. Mimar Sinan'ın imzasının taşıyan ve hamisi olan Van Beylerbeyi Hüsrev Paşa Külliyesi 1915-2009 yılları arasında kesintiye uğramasına rağmen, günümüzde Osmanlı Devleti'nin doğudaki mührü ve tapusu olarak ayakta durmaktadır. 


\section{Kaynakça}

Ağaoğlu, S. (2007). Van şehir dokusu ve tarihi eserlerinin tahrip edilmesinde Ermenilerin rolü. Atatürk Üniversitesi Türkiyat Araştırmalarl Enstitüsü Dergisi, 35, 328-330. https://dergipark.org.tr/tr/pub/ ataunitaed/issue/2874/39395

Aslanapa, O. (1999). Türk sanatı. Remzi Kitabevi.

Aytekin, O. (1995, 22-25 Mayıs). Eski eser kaçakçılı̆̆ı-tarihi ve Van yöresindeki yansımaları. Van Gölü Çevresi Kültür Varlıkları Sempozyumu [Konferans sunumu], Yüzüncü Y1l Üniversitesi, Van, Türkiye.

Belli, V. E. (2009). Van Hüsrev Paşa Camisi'ndeki taş, çini ve kalem işi süslemelerin bozulma nedenleri (Tez No. 284825) [Yüksek Lisans Tezi, Kadir Has Üniversitesi]. Yüksek Öğretim Kurulu Tez Merkezi.

Boran, A. (1994). Van Gölü çevresindeki tek kubbeli camilerin Türk sanatındaki yeri [Yayımlanmamış Yüksek Lisans Tezi]. Yüzüncü Y1l Üniversitesi Sosyal Bilimler Enstitüsü.

Dönmez, E. (2001). Türk çini sanatının sürekliliği içinde XVII. yüzyıl eserlerinin yeri (Tez No. 104899) [Doktora Tezi, İstanbul Üniversitesi]. Yüksek Öğretim Kurulu Tez Merkezi.

Eyice, S. (1999). İstanbul'da son devir Bizans mimarisi. Türkiye Diyanet Vakfi İslam Ansiklopedisi Cilt 19 (s. 49 51) içinde. https://islamansiklopedisi.org.tr/muellif/semavi-eyice

Günel, F. M. (1993). Eski Van kent dokusu üzerine bir deneme [Yayımlanmamış Yüksek Lisans Tezi]. Yüzüncü Y1l Üniversitesi Sosyal Bilimler Enstitüsü.

Kılıç, O. (1997). XVI. ve XVII. yüzyıllarda Van. Acar Matbaacılık.

Kuran, A. (1986). Mimar Sinan. Hürriyet Vakıf Yayınları.

Mercan, N. (2001). Hüsrev Paşa Camii kalem işi ve çini süslemeleri (Tez No. 109297) [Yüksek Lisans Tezi, Yüzüncü Yıl Üniversitesi]. Yüksek Öğretim Kurulu Tez Merkezi.

Meriç, R. M. (1965). Mimar Sinan'ın hayatı ve eserleri. Türk Tarih Kurumu Basımevi.

Öney, G. (1976). Türk çini sanatı. Yapı ve Kredi Bankası Yayınları.

Öztürk, Ş. (1996). Van-Ahlat ve Adilcevaz'daki tarihi camilerin rölöve proje çalışmaları (Tez No. 51232) [Yüksek Lisans Tezi, Yüzüncü Yıl Üniversitesi]. Yüksek Öğretim Kurulu Tez Merkezi.

Öztürk, Ş. (2004). Mimarlık ve kent, turkuaz: Denizin coğrafyasında Van, eski Van şehri. TMMOB Mimarlık Dergisi, 317, 52-54. http://www.mimarlikdergisi.com/index.cfm?sayfa=mimarlik\&DergiSayi=29\&RecID= $\underline{433}$

Öztürk, Ş. (2019). Van Hüsrev Paşa Külliyesi Hanı kazı-rölöve- restitüsyon ve restorasyon koruma projesi hakkında bir araştırma. Uluslararası Sosyal Araştırmalar Dergisi, 13(69), 448-466. http://dx.doi.org/10. $\underline{17719 / \text { jisr.2020.3985 }}$

Öztürk, Ş. (2020a). Van Hüsrev Paşa Külliyesi. Gece Kitaplı̆̆ı.

Öztürk, Ş. (2020b). Van Hüsrev Paşa Külliyesi Camii koruma ve onarım çalışmaları. Journal of Turkish Studies, 15(1), 1237-1268. http://dx.doi.org/10.29228/TurkishStudies.40204

Öztürk, Ş. (t.y.). Hüsrev Paşa Camii görünüş, süsleme, çizim ve onarım görselleri [Fotoğraf]. Şahabettin Öztürk kişisel arşivi.

Sönmez, Z. (1988). Mimar Sinan ile ilgili tarihi yazmalar-belgeler. Mimar Sinan Üniversitesi Yayınları.

Talay, A. (1988). Bizim eller. İhlas Matbaacılık.

Tarhan, M. T. (1985, 20-24 Mayıs). Van Kalesi'nin ve Eski Van şehri’nin tarihi-milli park projesi üzerinde ön çalışmalar (I): Anıtlar. III. Araştırma Sonuçları Toplantısı [Konferans sunumu], Ankara. http://www.kulturvarliklari.gov.tr/sempozyum_pdf/kazilar/10_kazi_1.pdf

Uluçam, A. (2000). Ortaçă̆ ve sonrasında Van Gölü çevresi mimarlı̆̆ I. Türk Tarih Kurumu Basımevi.

Van Müzesi. (t.y.). Hüsrev Paşa Camii özgün çini görünüşüleri [Fotoğraf]. Van Müzesi arşivi.

VANTAM. (t.y.). Van kalesi ve eski Van şehir güneydoğu genel görünüşü [Fotoğraf]. VANTAM arşivi. 